\title{
Isoflurane-Sensitive Presynaptic R-Type Calcium Channels Contribute to Inhibitory Synaptic Transmission in the Rat Thalamus
}

\author{
Pavle M. Joksovic, ${ }^{1}$ Marco Weiergräber, ${ }^{4,5}$ WooYong Lee, ${ }^{1,3}$ Henrik Struck, ${ }^{4,5}$ Toni Schneider, ${ }^{4,5}$ and \\ Slobodan M. Todorovic ${ }^{1,2}$ \\ Departments of ${ }^{1}$ Anesthesiology and ${ }^{2}$ Neuroscience, University of Virginia School of Medicine, Charlottesville, Virginia 22908-0710, ${ }^{3}$ Department of \\ Anesthesiology and Pain Medicine, InJe University, Sanggyepaik Hospital, Seoul 139-707, South Korea, and ${ }^{4}$ Department of Neurophysiology and ${ }^{5}$ Center \\ for Molecular Medicine Cologne, University of Cologne, D-50931 Cologne, Germany
}

\begin{abstract}
Because inhibitory synaptic transmission is a major mechanism of general anesthesia, we examined the effects of isoflurane on properties of GABAergic inhibitory currents in the reticular thalamic nucleus (nRT) in brain slices. The evoked IPSCs (eIPSCs) and spontaneous miniature synaptic currents (mIPSCs) of visualized nRT cells in young and adult rats were recorded. Consistent with postsynaptic effects on $\mathrm{GABA}_{\mathrm{A}}$ receptors, isoflurane prolonged the decay-time constants of both eIPSCs and mIPCSs. Surprisingly, isoflurane completely inhibited the amplitude of eIPSCs at clinically relevant concentrations ( $\mathrm{IC}_{50}$ of $240 \pm 20 \mu \mathrm{M}$ ), increased the paired-pulse ratio, and decreased the frequency of mIPSCs, indicating that presynaptic mechanisms may also contribute to the effects of isoflurane on IPSCs. The overall effect of isoflurane on eIPSCs in nRT cells was a decrease of net charge-transfer across the postsynaptic membrane. The application of $100 \mu \mathrm{m}$ nickel $\left(\mathrm{Ni}^{2+}\right)$ and the more specific R-type $\mathrm{Ca}^{2+}$ channel blocker SNX-482 $(0.5 \mu \mathrm{M})$ decreased eIPSC amplitudes, increased the paired-pulse ratio, and attenuated isoflurane-induced inhibition of eIPSCs. In addition, isoflurane potently blocked currents in recombinant human $\mathrm{Ca}_{\mathrm{V}} 2.3(\alpha 1 \mathrm{E})$ channels with an $\mathrm{IC}_{50}$ of $206 \pm 22 \mu \mathrm{M}$. Importantly, in vivo electroencephalographic (EEG) recordings in adult $\mathrm{Ca}_{\mathrm{v}} 2.3$ knock-out mice demonstrated alterations in isoflurane-induced burst-suppression activity. Because the thalamus has a key function in processing sensory information, sleep, and cognition, modulation of its GABAergic tone by presynaptic $\mathrm{R}_{-}$type $\mathrm{Ca}^{2+}$ channels may contribute to the clinical effects of general anesthesia.
\end{abstract}

Key words: anesthesia; calcium channels; calcium current; $\mathrm{GABA}_{\mathrm{A}}$ receptor; $\mathrm{GABAergic}$ neuron; thalamus

\section{Introduction}

Recent studies have suggested that general anesthetics act through specific ion channels to inhibit neuronal excitability. It is now known that some ligand-gated channels such as $\mathrm{GABA}_{\mathrm{A}}$ (Franks, 2008), NMDA (Jevtović-Todorović et al., 1998; Mennerick et al., 1998), as well as background (leak) potassium channels (Franks, 2008), are sensitive to anesthetics. Furthermore, some studies (Herrington et al., 1991; Takenoshita and Steinbach, 1991; Study, 1994; McDowell et al., 1996; Todorovic and Lingle, 1998) indicate that voltage-gated $\mathrm{Ca}^{2+}$ channels are also affected by volatile general anesthetics at concentrations that occur under clinical conditions. On the basis of the membrane potential at which they activate, these channels are subdivided into high-voltage-activated (HVA) and low-voltage-activated (LVA), or transient (T-type) $\mathrm{Ca}^{2+}$ channels. Pharmacological

Received Nov. 20, 2008; revised Dec. 29, 2008; accepted Jan. 6, 2009.

This work was supported in part by National Institutes of Health Grant GM070726 to S.M.T. We thank Dr. Steven Mennerick for helpful comments on this manuscript and Dr. Karthik Rajasekaran, Dr. Howard Goodkin, and Matt Rannals for help with data analysis.

Correspondence should be addressed to Slobodan M. Todorovic, Department of Anesthesiology, University of Virginia Health System, Mail Box 800710, Charlottesville, VA 22908-0710. E-mail:st9d@virginia.edu.

D0I:10.1523/JNEUROSCI.5574-08.2009

Copyright $\odot 2009$ Society for Neuroscience $\quad$ 0270-6474/09/291434-12\$15.00/0 and physiological experiments support the existence of multiple types of native HVA $\mathrm{Ca}^{2+}$ channels (Catterall, 2000). These channels are products of different genes, which give rise to $\alpha 1$ subunits that form the pores of the neuronal $\mathrm{Ca}^{2+}$ channels named $\mathrm{Ca}_{\mathrm{V}} 1$ family (former $\alpha 1 \mathrm{~S}, \alpha 1 \mathrm{C}, \alpha 1 \mathrm{D}, \alpha 1 \mathrm{~F}$ ) encoding Ltype; $\mathrm{Ca}_{\mathrm{V}} 2.1(\alpha 1 \mathrm{~A})$ encoding P/Q-type; $\mathrm{Ca}_{\mathrm{V}} 2.2(\alpha 1 \mathrm{~B})$ encoding $\mathrm{N}$-type; and $\mathrm{Ca}_{\mathrm{V}} 2.3(\alpha 1 \mathrm{E})$ encoding R-type. These channels in neurons have a central function in sensory, cognitive, and motor pathways by controlling cell excitability and neurotransmitter release. Despite the determined sensitivities of certain $\mathrm{Ca}^{2+}$ channels to anesthetic blockade, previous studies have not conclusively established that presynaptic $\mathrm{Ca}^{2+}$ channels in neurons are sites of anesthetic action. This is important because small changes in $\mathrm{Ca}^{2+}$ influx into presynaptic terminals can result in profound changes in transmitter release and synaptic efficacy (Wu and Saggau, 1997). Thus, even if $\mathrm{Ca}^{2+}$ channels are only partially blocked by anesthetics at concentrations within the clinically relevant range, it is important to determine the effects of anesthetics on presynaptic neuronal $\mathrm{Ca}^{2+}$ channels.

There is growing recognition that thalamic nuclei are important in awareness and cognitive functions (Kinney et al., 1994; McCormick and Bal, 1997; Llinás et al., 1999; Alkire et al., 2000). The rhythmicity of this complex circuitry depends to a great ex- 
tent on the ability of thalamic cells to burst in oscillatory patterns. A key element in rhythm generation within the thalamus is the GABAergic nucleus reticularis thalami (nRT), which is not only reciprocally connected to thalamocortical relay neurons of dorsal thalamic nuclei, but also receives collateral excitatory connections from corticothalamic and thalamocortical fibers (Jones, 1985). In addition, nRT neurons create numerous axonal and dendrodendritic synapses that can inhibit one another (SanchezVives et al., 1997; Shu and McCormick, 2002) and may receive GABAergic inputs from other forebrain structures as well (Jourdain et al., 1989; Paré et al., 1990; Asanuma, 1994). Earlier in vivo extracellular recordings have shown that volatile general anesthetics modulate synaptic transmission and depress the excitability of thalamic neurons, which in turn causes blockade of thalamocortical information transfer (Angel, 1991; Detsch et al., 2002; Vahle-Hinz et al., 2007a,b). Thus, we hypothesized that voltage-gated $\mathrm{Ca}^{2+}$ channels that support fast synaptic transmission in nRT neurons may be affected by isoflurane, the prototypical volatile general anesthetic.

\section{Materials and Methods}

In vitro tissue slice preparation

Most experiments were done on transverse rat brain slices taken through the middle anterior portion of the nRT (Paxinos and Watson, 1986). Sprague Dawley rats were housed in the local animal facility in accordance with protocols approved by the University of Virginia Animal Use and Care Committee. All treatment of rats adhered to the guidelines in the NIH Guide for the Care and Use of Laboratory Animals.

Rats [postembryonic day 7 (P7-28)] were briefly anesthetized with isoflurane and decapitated. The brains were rapidly removed and placed in chilled $\left(4^{\circ} \mathrm{C}\right)$ cutting solution consisting, in mM, of $2 \mathrm{CaCl}_{2}, 260$ sucrose, $26 \mathrm{NaHCO}_{3}, 10$ glucose, $3 \mathrm{KCl}, 1.25 \mathrm{NaH}_{2} \mathrm{PO}_{4}$, and $2 \mathrm{MgCl}_{2}$ equilibrated with a mixture of $95 \% \mathrm{O}_{2}$ and $5 \% \mathrm{CO}_{2}$. A block of tissue containing the thalamus was glued to the chuck of a vibratome (World Precision Instruments) and 250-300 $\mu \mathrm{m}$ slices were cut in a transverse plane. The slices were incubated in $36^{\circ} \mathrm{C}$ oxygenated saline for $1 \mathrm{~h}$, then placed in a recording chamber that had been superfused with extracellular saline at a rate of $1.5 \mathrm{cc} / \mathrm{min}$. Incubating saline consisted, in $\mathrm{mM}$, of 124 $\mathrm{NaCl}, 4 \mathrm{KCl}, 26 \mathrm{NaHCO}_{3}, 1.25 \mathrm{NaH}_{2} \mathrm{PO}_{4}, 2 \mathrm{MgCl}_{2}, 10$ glucose, and 2 $\mathrm{CaCl}_{2}$ equilibrated with a mixture of $95 \% \mathrm{O}_{2}$ and $5 \% \mathrm{CO}_{2}$. Slices were maintained in the recording chamber at room temperature and remained viable for at least $1 \mathrm{~h}$. Because the half-life of halogenated volatile anesthetics in nerve tissue after induction of anesthesia is only $\sim 10 \mathrm{~min}$ (Stevens and Kingston 1992), it is unlikely that the isoflurane used to euthanize animals could have interfered with the results of our experiments, which were performed at least $2 \mathrm{~h}$ later.

\section{Recording procedures}

The standard extracellular saline for recording of IPSCs and voltagegated $\mathrm{Ca}^{2+}$ currents in brain slices consisted, in $\mathrm{mm}$, of $2 \mathrm{CaCl}_{2}, 130$ $\mathrm{NaCl}, 1 \mathrm{MgCl}_{2}, 10$ glucose, $26 \mathrm{NaHCO}_{3}, 1.25 \mathrm{NaH}_{2} \mathrm{PO}_{4}$, and $2 \mathrm{~mm} \mathrm{KCl}$ equilibrated with a mixture of $95 \% \mathrm{O}_{2}$ and $5 \% \mathrm{CO}_{2}$. For recording $\mathrm{GABA}_{\mathrm{A}}$ evoked (eIPSC) and miniature (mIPSC) IPSCs, we used internal solution containing, in mM, $130 \mathrm{KCl}, 4 \mathrm{NaCl}, 0.5 \mathrm{CaCl}_{2}, 5 \mathrm{EGTA}, 10$ HEPES, $2 \mathrm{MgATP}_{2}$, and 0.5 Tris-GTP. For recording mIPSC, $5 \mathrm{~mm} \mathrm{Li}$ docaine $N$-ethyl bromide was added to the internal solution and $0.5 \mu \mathrm{M}$ TTX was added to the external solution to prevent the influence of action potentials on neurotransmitter release. To eliminate glutamatergic excitatory currents, all recordings of IPSCs were done in the presence of $5 \mu \mathrm{M}$ NBQX (2,3-dihydroxy-6-nitro-7-sulfamoyl-benzo[f] quinoxaline-2,3dione) and $50 \mu \mathrm{M}$ D-APV $((2 R)$-amino-5-phosphonovaleric acid; AP5 $(2 R)$-amino-5 phosphonopentanoate). For a subset of recordings of eIPSCs from nRT neurons, we included in our external solution $100 \mathrm{~nm}$ CGP55845A [(2S)-3-[[(1S)-1-(3,4-dichlorophenyl)ethyl] amino-2hydroxypropyl] (phenylmethyl)phosphinic acid], a specific $\mathrm{GABA}_{\mathrm{B}}$ receptor antagonist.

For recordings of HVA Ca ${ }^{2+}$ current in HEK recombinant cells and intact brain slices, we used internal solution containing, in $\mathrm{mm}, 110$ Cs-methane sulfonate, 14 phosphocreatine, 10 HEPES, 9 EGTA, 5 MgATP, and 0.3 Tris-GTP, $\mathrm{pH}$ adjusted to 7.15-7.20 with CsOH. The external solution used to record recombinant $\mathrm{Ca}_{\mathrm{V}} 2.3 \mathrm{Ca}^{2+}$ currents contained, in $\mathrm{mm}, 2 \mathrm{BaCl}_{2}, 152 \mathrm{TEA}-\mathrm{Cl}$, and 10 HEPES adjusted to $\mathrm{pH} 7.4$ with TEA-OH. Whole-cell recordings were obtained from nRT neurons visualized with an IR DIC camera (Hammamatsu, C2400) on the Zeiss 2 FS Axioscope (Carl Zeiss) with a $40 \times$ lens.

\section{Electrophysiological recordings}

We recorded $\mathrm{GABA}_{\mathrm{A}}$-evoked and miniature IPSCs in thalamic slices from a total of 193 visually identified nRT and 6 thalamocortical (TC) relay neurons ( $R$ values $<20 \mathrm{M} \Omega$ ). Synaptic stimulation of $\mathrm{nRT}$ neurons was achieved with a Constant Current Isolated Stimulator DS3 (Digitimer Ltd.) and electrical field stimulation achieved either by placing a stimulating electrode in the outer region of the internal capsule (see Fig. $1 A$ ) or within the nRT soma layer. Recordings were made with standard whole-cell voltage clamp technique. Electrodes were fabricated from thin-walled microcapillary glass with final resistances of 3-6 $\mathrm{M} \Omega$; membrane currents were recorded with an Axoclamp 200B amplifier (Molecular Devices). Voltage commands and digitization of membrane currents were done with Clampex 8.2 of the pClamp software package (Molecular Devices) running on an IBM-compatible computer. Neurons were typically held at $-70 \mathrm{mV}$.

Currents were filtered at $5 \mathrm{kHz}$. Series resistance was typically compensated by $50-80 \%$ during experiments. In most experiments, during recordings of recombinant and native HVA currents, a $\mathrm{P} / 5$ protocol was used for on-line leakage subtractions. HEK293 cells were stably transfected with both the $\alpha 1 \mathrm{E}\left(\mathrm{Ca}_{\mathrm{V}} 2.3\right)$ and $\beta 3 \mathrm{Ca}^{2+}$ channel subunits as described previously (Nakashima et al., 1998). Cells were typically used 1-4 d after plating. Steps used to activate $\mathrm{Ca}_{\mathrm{V}} 2.3$-generated currents in HEK cells in whole-cell experiments were typically from a holding potential $\left(V_{\mathrm{h}}\right)$ of $-70 \mathrm{mV}$ to test potentials $\left(V_{\mathrm{t}}\right)$ at $0 \mathrm{mV}$.

\section{Analysis of current}

Current waveforms or extracted data were fitted using Clampfit 8.2 (Molecular Devices), Mini Analysis Program 6.0 (Synaptosoft) and Origin 7.0 (OriginLab). The decay of eIPSCs and mIPSCs was estimated by a single-or double-exponential term. If double exponential function was done, we used weighted averages for our analyses. The limit for mIPSCs detection was set in most recordings at three times the root mean square of baseline noise. The accuracy of detection was visually verified. The amplitudes of all mIPSCs greater than the detection criteria were included in the amplitude analysis.

The percentage reduction in peak current at a given blocker concentration was used to generate concentration-response curves. For each concentration-response curve, all points are averages of multiple determinations from at least six different cells. Mean values in concentrationresponse curves were fitted to the following (Hill-equation) function: $\mathrm{PB}([$ Drug $])=\mathrm{PB}_{\max } / 1+\left(\mathrm{IC}_{50} /[\text { Drug }]\right)^{n}$, where $\mathrm{PB}_{\max }$ is the maximal percentage block of peak eIPSCs or $\mathrm{IBa}^{2+}$, the $\mathrm{IC}_{50}$ is the concentration that produced $50 \%$ of maximal inhibition, and $n$ is the apparent Hill coefficient for blockade. Fitted values were typically reported with $95 \%$ linear confidence limits. Fitting was done with Origin 7.0. Numerical values are given in the text as means \pm SEM unless stated otherwise. Statistical analysis was done with paired or unpaired Student's $t$ test where indicated, with statistical significance determined with $p<0.05$.

\section{Drugs and chemicals}

Tetrodotoxin (TTX) was obtained from Alomone Labs. SNX-482, Omega-Agatoxin IVA, and Omega-Conotoxin MVIIC were obtained from Peptides International. Isoflurane was obtained from Abbott. All other salts and chemicals were obtained from Sigma Chemical. The following drugs were prepared as stock solutions: TTX, $5 \mu \mathrm{M}$; NBQX and APV, 5 mm; SNX-482, Omega-Agatoxin IVA and Omega-Conotoxin MVIIC, $500 \mu \mathrm{M} ; \mathrm{Ni}^{2+}, 100 \mathrm{~mm}$ and picrotoxin, $20 \mathrm{~mm}$. Drugs were freshly diluted to the appropriate concentrations at the time of experiments. All stocks were prepared in $\mathrm{H}_{2} \mathrm{O}$ except for $\mathrm{NBQX}$ and picrotoxin, which were prepared in DMSO. The maximum final concentration of 
DMSO in any one experiment was $0.1 \%$; at that concentration, DMSO has no effect on eIPSCs in nRT cells ( $n=3$, data not shown).

\section{Solutions}

A glass syringe served as a reservoir for a gravity-driven perfusion system consisting of multiple independently controlled glass capillary tubes.

Manually controlled valves allowed switching between solutions. All experiments were done at room temperature $\left(20-24^{\circ} \mathrm{C}\right)$. Aliquots of anesthetic solutions were prepared from saturated saline solutions incubated with isoflurane $(60 \mathrm{cc}$ of saline with $40 \mathrm{cc}$ of isoflurane in a closed $100 \mathrm{cc}$ vial) for at least $24 \mathrm{~h}$ (Todorovic and Lingle, 1998; Todorovic et al., 2000; Joksovic et al., 2005). To quantify the actual anesthetic concentrations in solutions, we had analyzed samples of saturated stock solutions and aliquots in a gas chromatograph calibrated with appropriate volatile anesthetic standards (Todorovic and Lingle, 1998; Joksovic et al., 2005). By measuring actual concentrations, we found a loss of $<10 \%$ if the solution was used within $30 \mathrm{~min}$ after preparation. Thus, all anesthetic solutions were used within $30 \mathrm{~min}$ after preparation. Test solutions were maintained in all-glass syringes tightly sealed with Parafilm punctured with a small escape hole when a whole-cell was obtained that allowed anesthetic solution to fall by gravity. All stock solutions were freshly diluted to appropriate concentrations at the time of an experiment. During an experiment, solution was removed from the end of the recording chamber opposite the glass capillary tubes by constant suction. Changes in current amplitudes in response to rapidly acting drugs or ionic changes are typically complete in $2-4 \mathrm{~min}$. Switching between separate perfusion syringes, each containing control saline, resulted in no changes in the amplitude of IPCSs, $\mathrm{IBa}^{2+}$ or $\mathrm{ICa}^{2+}$.

\section{Methodological considerations}

By necessity, thalamic slices were obtained from young rats. With current technology, direct visualization of nRT neurons in this heavily reticulated region of the thalamus of adult animals is difficult. Importantly, we performed a limited number of recordings in slices from adult rats (older than P21) as shown in Figure 3B, demonstrating qualitatively similar results of isoflurane modulation of eIPSCs.

Because voltage control is compromised in whole-cell recordings from slices because of the presence of extensive cell processes, we paid close attention to good voltage control, ensuring that there was no extensive delay in the onset of current and that the onset and offset kinetics depended on voltage, not on the amplitude of current. Because intact nRT neurons have long processes, rapid components of recorded current, such as fast-activation kinetics or tail currents, are not likely to reflect the true amplitude and time course of $\mathrm{Ca}^{2+}$ current behavior. However, all our measurements of amplitudes from holding, peak, and steady-state currents were made at time points sufficient to ensure reasonably well clamped current conditions. Furthermore, using brain slices from young animals, in which dendritic processes are not fully developed, ameliorated the space-clamp problem.

We applied all drugs in intact brain slices until an apparent equilibrium was reached. Delivery of lipid-soluble substances such as isoflurane to intact tissue slices is compromised by a decline in drug concentrations along the length of the bath and diffusion through the tissue. Thus, although our method allowed investigation of the effects of anesthetic agents in intact native cells, all quantitative assessments should be taken with caution. Actual effective concentrations of all drugs are likely to be lower than those reported.

\section{In vivo EEG recordings}

Study animals. Generation of the $\mathrm{Ca}_{\mathrm{v}} 2.3$ null mutant, which was backcrossed into C57BL/6, has been described in detail (Pereverzev et al., 2002; Weiergräber et al., 2006). Mice were housed in Makrolon cages type II and maintained on a conventional $12 \mathrm{~h}$ light/dark cycle with food and water available ad libitum. All animal experimentation was approved by the Committee on Animal Care of the University of Cologne. All efforts were made to minimize animal suffering and to use only the number of animals necessary to produce reliable data.

Telemetric EEG recordings. The TA10ETA-F20 radiotransmitter (Data Sciences International, Transsoma Medical) was used for electrocorticographic (ECoG) recordings in $\mathrm{Ca}_{\mathrm{v}} 2.3^{-1-}$ and control mice. The teleme- try system, anesthesia, implantation procedure and postoperative treatment have been described in detail (Weiergräber et al., 2005).

Surface electrode implantation. In all, three $\mathrm{Ca}_{\mathrm{v}} 2.3^{+/+}$mice $(21.62 \pm$ 2.71 weeks old) and three $\mathrm{Ca}_{\mathrm{v}} 2.3^{-1-}$ animals $(22.14 \pm 0.29$ weeks old $)$ were studied. Epidural leads were positioned above the somatosensory cortex at the following stereotaxic coordinates: $(+)$-lead, bregma -1 $\mathrm{mm}$, lateral of bregma $2.5 \mathrm{~mm}$ (right hemisphere); (-)-lead, bregma -1 $\mathrm{mm}$, lateral of bregma $2.5 \mathrm{~mm}$ (left hemisphere). Leads were fixed at the underlying neurocranium with glass ionomer cement. Radiotransmitterimplanted $\mathrm{Ca}_{\mathrm{v}} 2.3^{-1-}$ and control mice were given at least $11 \mathrm{~d}(16.00 \pm$ $2.65, n=3$ vs $14.67 \pm 1.86, n=3$ ) to fully recover after surgery.

Isoflurane treatment of EEG-radiotransmitter implanted mice. Isoflurane was given at $1 \%$, using a calibrated vaporizer in the presence of oxygen (2 $1 / \mathrm{min}$ flow). Mice were given $30 \mathrm{~min}$ of equilibration time after the administration of isoflurane, followed by a 30-min ECoG recording used for later analysis. During the complete experimental procedure, mice's body temperature was maintained using a heating support with a semicircular recess and continuously monitored by the implanted radiotransmitter.

Data acquisition and analysis. We used A.R.T. 4.1 software (Data Sciences International) to acquire and analyze EEG data. Dataquest EEG recordings under isoflurane treatment were obtained throughout the complete $2 \mathrm{~h}$ exposure period. In addition, long-term ECoGs (up to $24 \mathrm{~h}$ ) were obtained before isoflurane treatment. EEG activity was sampled at $1000 \mathrm{~Hz}$ with no filter cutoff. After the isoflurane equilibration phase, mice exhibited typical EEG patterns of repetitive transient sequences of high-voltage slow waves intermingled with sharp waves, or bursts; these episodes alternated with periods of depressed background activity or complete EEG flatness, termed suppression. The time of individual bursts and suppression episodes was analyzed together with their frequencies; the suppression to burst ratio was also calculated. Burst episodes of $2 \mathrm{~s}$ duration were analyzed by power spectrum density (PSD) analysis (Dataquest A.R.T. 4.1 software, Data Sciences International) to reveal frequency distribution and burst peak frequency. All data were calculated and are shown as the means \pm SEM with $p<0.05$ considered to be significant.

\section{Results}

\section{Electrophysiological characterization of evoked $\mathrm{GABA}_{\mathrm{A}}$ IPSCs in nRT cells}

The thalamic nRT is a thin layer of cells that surrounds the thalamus and segregates it from the internal capsule (IC). Stimulation of fibers in close proximity to the internal capsule $(\sim 200 \mu \mathrm{m}$ from recorded cells) (Fig. 1A) evokes picrotoxin-sensitive $\mathrm{GABA}_{\mathrm{A}}$ IPSCs (eIPSCs) in nRT neurons. Figure $1 B$ shows an example of eIPSCs with characteristic slow decay (Zhang et al., 1997; Huntsman and Huguenard, 2000) in which $20 \mu \mathrm{M}$ picrotoxin, a potent noncompetitive $\mathrm{GABA}_{\mathrm{A}}$ receptor antagonist, has completely blocked the amplitude of eIPSCs. The time course for the same experiment is shown on the right side of Figure $1 \mathrm{~B}$. It has been established that synaptic transmission is triggered by $\mathrm{Ca}^{2+}$ ion entry into presynaptic nerve terminals (Katz and Miledi, 1970). To confirm the $\mathrm{Ca}^{2+}$ dependency of eIPSC in nRT neurons, we made recordings in a solution containing $1 \mathrm{mM}$ $\mathrm{Ca}^{2+}$, finding that the size of eIPSCs decreased by $37 \pm 8 \%(n=$ $5, p<0.05$ ) (Fig. $1 C$ ). Furthermore, elimination of $\mathrm{Ca}^{2+}$ ions from extracellular media (within an average of 2-4 min) almost completely and reversibly eliminated the development of eIPSCs on introduction of nominal $\mathrm{Ca}^{2+}$-free recording solution. A same-strength stimulus evoked IPSCs on reintroduction of $2 \mathrm{~mm}$ $\mathrm{Ca}^{2+}$ into our recording medium (Fig. 1D).

Previous recordings of $\mathrm{HVA} \mathrm{Ca}{ }^{2+}$ currents in acutely isolated nRT neurons demonstrated that a significant portion of current was sensitive to $\mathrm{Ni}^{2+}$ (Huguenard and Prince, 1992), a preferential blocker of R-type voltage-gated $\mathrm{Ca}^{2+}$ channels (Zamponi et al., 1996). Thus, we reasoned that eIPSCs in these cells could depend on $\mathrm{R}$-type $\mathrm{Ca}^{2+}$ channels. To test this hypothesis, we 
A

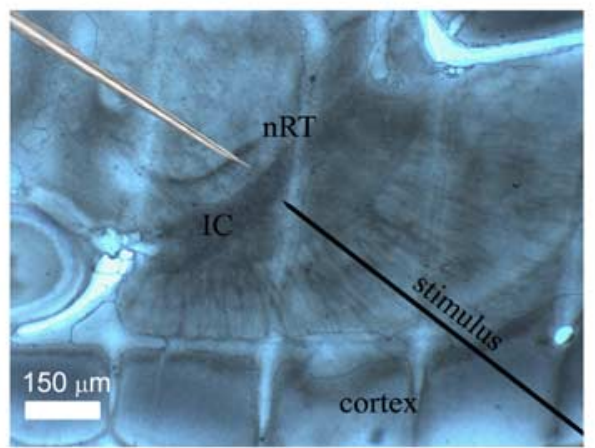

C
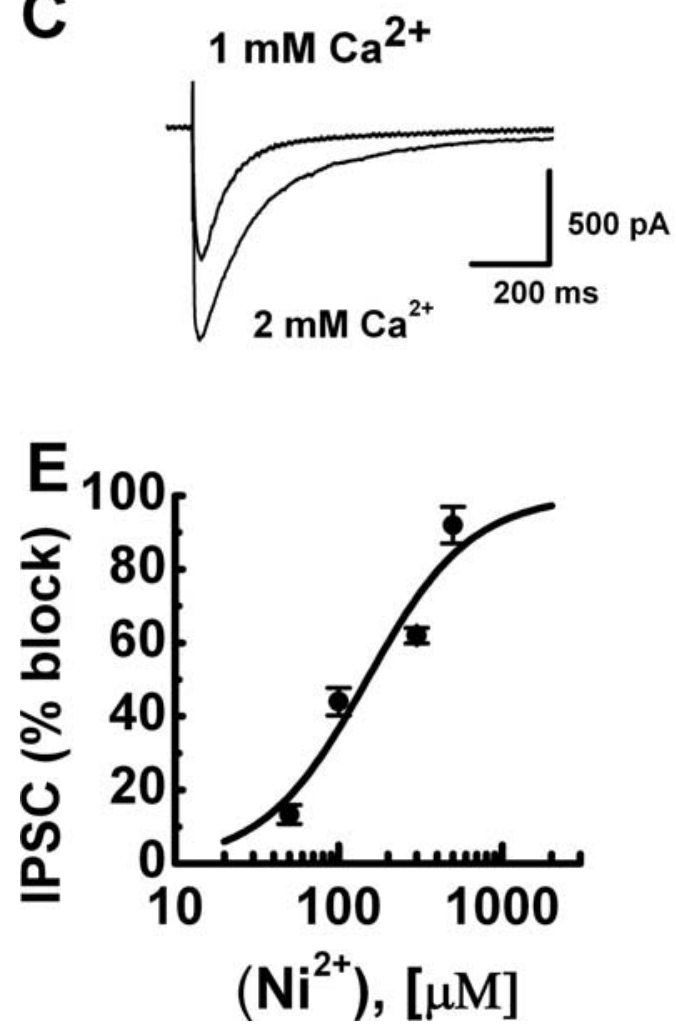

B
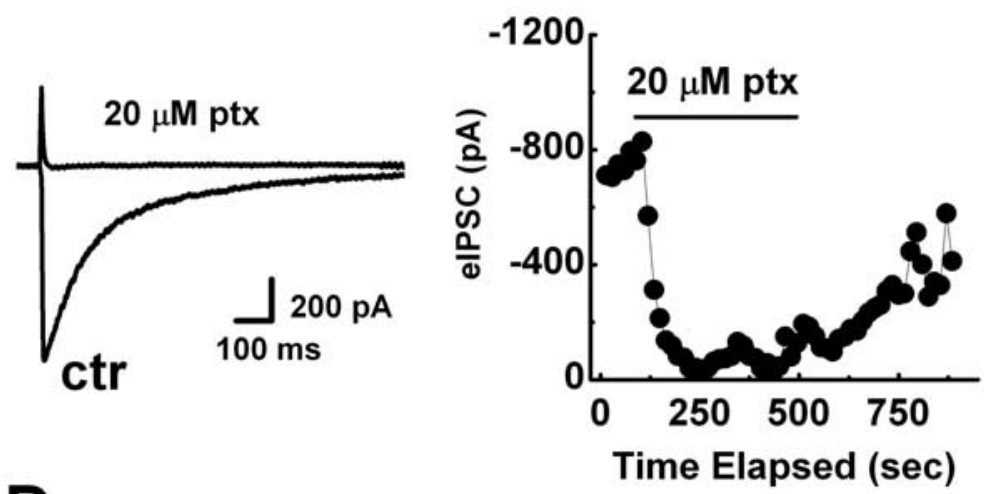

D
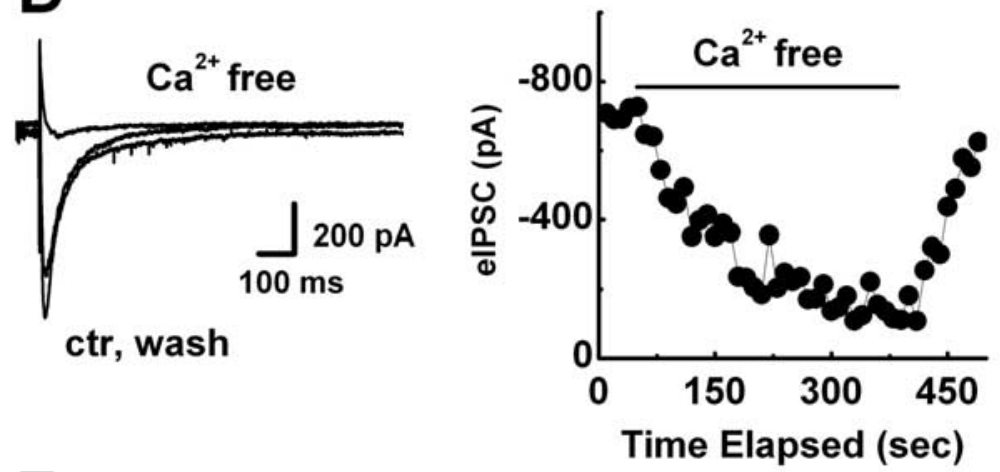

$\mathbf{F}$
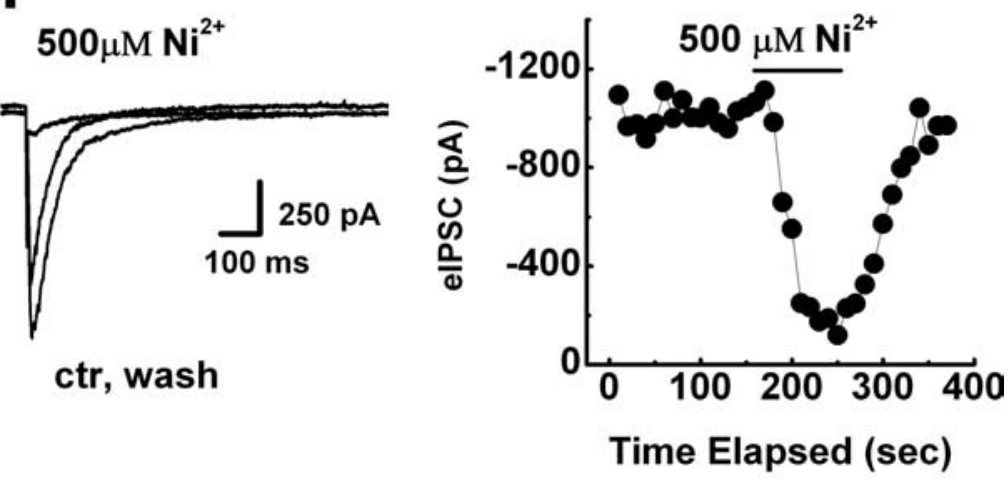

Figure 1. Isolation of elPSCs in $n R T$ cells in intact brain slices. $A$, Images showing stimulating (outer part of IC) and recording electrode (nRT). Evoked GABA $A_{A}$-ergic IPSCS were elicited by

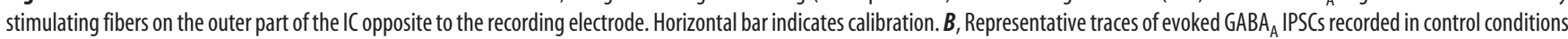
and in the presence of $20 \mu \mathrm{m}$ picrotoxin (ptx), a selective $G_{A B A_{A}}$ and receptor antagonist (on the left). Time course from the same cell showing the partially reversible, potent, and fast blocking effect of picrotoxin (on the right). C, elPSCs traces recorded in the presence of 1 and $2 \mathrm{~mm}$ external calcium. Note faster current decay with $1 \mathrm{~mm}$ than $2 \mathrm{~mm} \mathrm{Ca}^{2+}$. The decay time constant decreased to 88

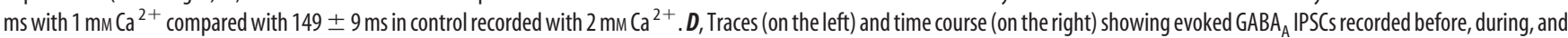
after the application of nominal $\mathrm{Ca}^{2+}$-free external solution. $\boldsymbol{E}$, Concentration-response curve showing the blocking effect of 50, 100, 300, and $500 \mu \mathrm{M} \mathrm{Ni}{ }^{2+}$ on elPSC in nRT neurons, yielding IC 50 of $150 \pm 33 \mu \mathrm{m}$ and slope constant $1.4 \pm 0.4$. Each point represents mean value calculated from at least 6 neurons. Vertical bars represent mean SEs. $\boldsymbol{F}$, Traces on the left and time course on the right show the reversible effect of $500 \mu \mathrm{m} \mathrm{Ni}{ }^{2+}$ on evoked IPSCs. Horizontal bar represents duration of application.

recorded eIPSCs in the presence of different concentrations of $\mathrm{Ni}^{2+}$ in the external solution. We found that $\mathrm{Ni}^{2+}$ at $50,100,300$, and $500 \mu \mathrm{M}$ reversibly and almost completely inhibited the amplitude of total eIPSCs in these cells, yielding an $\mathrm{IC}_{50}$ of $150 \pm 33$ $\mu \mathrm{M}$ and a slope factor $n$ of $1.4 \pm 0.4(n=27$ cells). Concentration-response curve and representative traces and time course of the effect of $\mathrm{Ni}^{2+}$ on eIPSC in nRT cells are shown in Figure 1, $E$ and $F$.

The effect of isoflurane on IPSCs in nRT cells

We tested the effect of clinically relevant concentrations $(75,150$, 300 , and $600 \mu \mathrm{M}$ ) of isoflurane on $\mathrm{GABA}_{\mathrm{A}}$-dependent eIPSCs in the nucleus reticularis thalami. Isoflurane reversibly and almost completely decreased the peak of eIPSCs evoked via stimulating electrode under constant-strength current injections (Fig. 2A, $B$ ), with an $\mathrm{IC}_{50}$ of $240 \pm 20 \mu \mathrm{M}$ and a slope factor $n$ of $1.43 \pm 0.19$ ( $n=28$ cells) (Fig. 2C). In addition, $300 \mu \mathrm{M}$ isoflurane increased the decay-time constant of eIPSCs by $40 \pm 2 \%$ (Fig. $2 A)(n=9$ cells, $p<0.05$; note the criss-crossing pattern of eIPSCs decay). However, despite the effects on decay-time constant, total charge transfer was decreased in the presence of isoflurane by $40 \pm 7 \%$ $(n=14, p<0.01)$. Also, at concentrations of 75 and $150 \mu \mathrm{M}$, isoflurane did not significantly affect the decay-time constant of eIPSCs (data not shown). In the presence of the specific $\mathrm{GABA}_{\mathrm{B}}$ 
A nRT cell
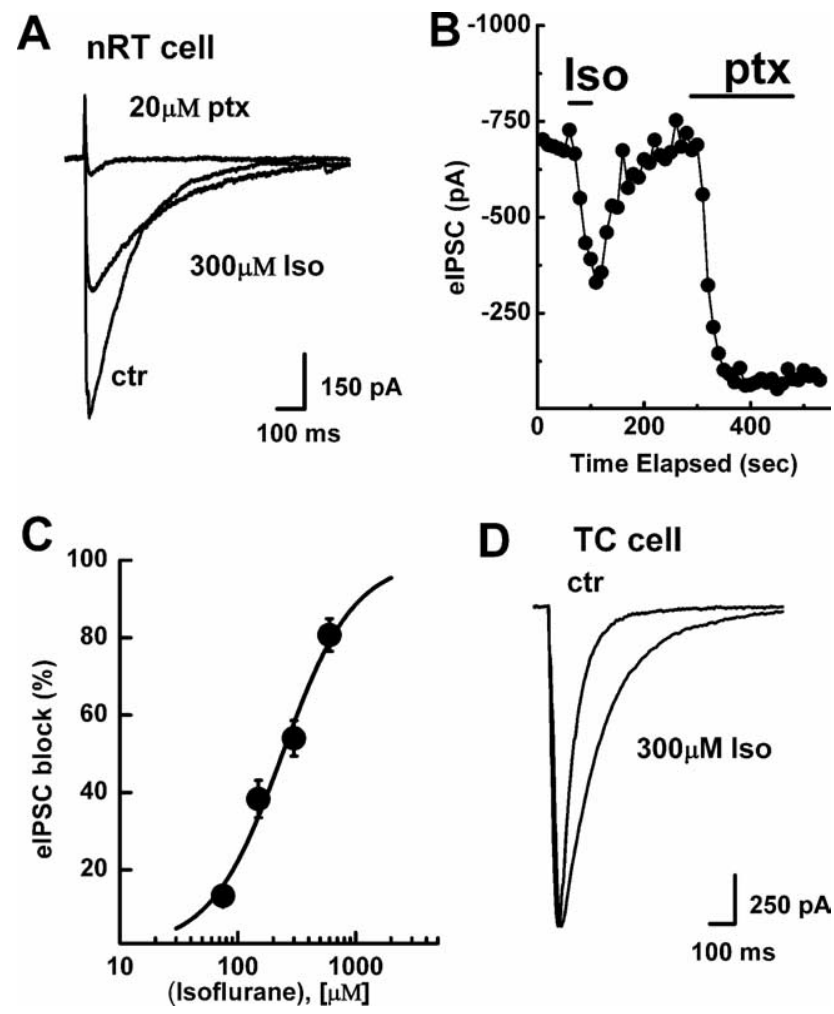

D TC cell ctr

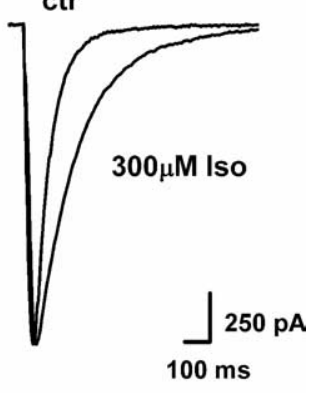

Figure 2. Nucleus-specific effects of isoflurane applications on eIPSCs in the thalamus. Panel shows representative traces $(\boldsymbol{A})$ and time course $(\boldsymbol{B})$ of the effects of isoflurane (Iso) and picrotoxin (ptx) on elPSCs in an nRT neuron. Peak values of elPSCs were plotted as a function of time showing the reversible blocking effect of $300 \mu \mathrm{m}$ isoflurane and the almost complete block of eIPSCs with $20 \mu \mathrm{m}$ picrotoxin. Horizontal bars indicate duration of isoflurane and picrotoxin application. Note that isoflurane caused a slight prolongation of elPSC decay as shown by criss-crossing of current traces before and during its application. C, Concentration-response curve showing the blocking effect of isoflurane on elPSCs in nRT neurons. The curve is best fitted with Hill function, yielding an $\mathrm{I}_{50}$ of $240 \pm 20 \mu \mathrm{m}$ and a slope constant of $1.4 \pm 0.2$. Each point represents mean value calculated from at least 6 neurons. Vertical bars represent mean SEs. $\boldsymbol{D}$, Representative traces of elPSCs in a TC cell in control conditions and during application of 300 $\mu \mathrm{m}$ isoflurane. Note that isoflurane had minimal effect on the amplitude of current but increased decay time $>2$-fold (from 66 to $161 \mathrm{~ms}$ ).

receptor antagonist CGP55845A (100 nM), $300 \mu \mathrm{M}$ isoflurane inhibited the amplitude of eIPSCs to a similar degree (57 $\pm 7 \%$, $n=3, p<0.05$; data not shown).

Next we examined the effects of isoflurane on eIPSCs in thalamocortical (TC) relay cells of the ventrobasal complex, which receives most of the inhibitory projections from nRT cells. We placed the stimulating electrode within the nRT layer and recorded eIPSCs from cells in the ventrobasal complex up to 250 $\mu \mathrm{m}$ from nRT. Figure $2 D$ shows traces of typical eIPSCs before and during the application of $300 \mu \mathrm{M}$ isoflurane. In contrast to its effects in nRT cells, isoflurane caused minimal change in the amplitude of eIPSCs $(9 \pm 5 \%, n=6, p>0.05)$, but induced an approximately twofold prolongation of the decay-time constant from $71 \pm 10$ to $145 \pm 12 \mathrm{~ms}(n=6, p<0.01)$. As a result, total charge transfer was increased in the presence of isoflurane for $85 \pm 13 \%$ in TC cells $(p<0.01)$. This finding argues that the inhibitory effect of isoflurane on eIPSCs is synapse-specific for nRT.

To discern the site of isoflurane's action on eIPSCs in nRT neurons, we used paired-pulse analysis to examine the potential synaptic effects of presynaptic modulators (e.g., blockers of voltage-gated $\mathrm{Ca}^{2+}$ channels). This sensitive test is done by ana- lyzing changes in the ratio of eIPSCs elicited by two identical presynaptic stimuli delivered in rapid succession. In nRT neurons (Bessaï et al., 2006) and other synapses (reviewed by Zucker and Regehr, 2002), stimulation with a paired-pulse stimulus interval of 0.01-10 s usually resulted in depression of the second (test) eIPSC compared with the first (conditioning) eIPSC. This depression of the test eIPSCs relative to the conditioning eIPSCs is believed to be caused by depletion of a fraction of readily available synaptic vesicles by the conditioning pulse (Zucker and Regehr, 2002). Presynaptic depressants that change the probability of transmitter release from presynaptic terminals will cause a smaller fraction of the readily releasable pool of vesicles to undergo exocytosis and therefore will decrease pairedpulse depression. This means that in the presence of presynaptic modulators, the ratio of test IPSCs to conditioning IPSCs becomes larger. However, if a modulator simply eliminates a fraction of the vesicle pool from availability or acts exclusively on postsynaptic sites, paired-pulse depression should remain unchanged.

Paired stimulation of afferent fibers resulted in paired-pulse depression, a highly characteristic finding for nRT neurons (Fig. $3 A, B)$. We found that $300 \mu \mathrm{M}$ isoflurane reversibly decreased the size of eIPSCs by $\sim 54 \%$ from the control level and significantly changed the paired-pulse ratio (PPR, eIPSC-2:eIPSC-1 ratio) from $0.86 \pm 0.02$ in controls to $0.95 \pm 0.02$, strongly suggesting its presynaptic effect ( $n=10$ cells, $p<0.05$ ) (Fig. $3 A, B)$. Being concerned about the fact that we were doing our recordings on neonatal and juvenile rats (P7-14), we next recorded the effects of isoflurane in slices older than P21. Figure $3 C$ shows the effects of $300 \mu \mathrm{M}$ isoflurane in thalamic slices from a P23 rat. The results were similar to those in younger rats, with isoflurane inhibiting $\sim 50 \%$ (average of $47 \pm 9 \%, p<0.01, n=5$ ) of the amplitude of eIPSCs and increasing PPR from $0.77 \pm 0.06$ in controls to $0.92 \pm$ 0.02 in experimental rats $(n=5, p<0.05)$ (Fig. $3 D)$. Isoflurane in these experiments also increased the decay-time constant of eIPSCs by $56 \pm 5 \%(p<0.001)$, but decreased net charge transfer for $29 \pm 7 \%(p<0.05)$. Hence, it appears that there are not important developmental changes in the effects of isoflurane on nRT eIPSCs.

To investigate the contribution of local axonal and dendrodendritic synapses, we recorded eIPSCs from decorticated slice preparations while stimulating neurons directly within nRT (typically closer than $40 \mu \mathrm{m}$ ). However, the addition of $300 \mu \mathrm{M}$ isoflurane to the external solution not only reversibly blocked eIPSCs by $55 \pm 4 \%(p<0.05, n=5$ cells $)$, but prolonged the decay-time constant by $20 \pm 2 \%(p<0.05)$ and increased paired-pulse ratio from $0.70 \pm 0.08$ to $0.86 \pm 0.02(p<0.05$; data not shown). Overall, our data from decorticated slices are consistent with our previous finding from intact thalamic slice preparations, suggesting that, regardless of the method of stimulation, isoflurane inhibits eIPSCs by a presynaptic mechanism.

To confirm that all the inhibitory effects of isoflurane on IPSCs are likely to be the result of actions on the presynaptic terminal, we also examined the effects of isoflurane on the $\mathrm{GABA}_{\mathrm{A}}$ evoked amplitude, duration, and frequency of spontaneous miniature synaptic currents (mIPSCs) in nRT neurons. In miniature synaptic currents, presynaptic effects alter the frequency of events, whereas postsynaptic effects alter the amplitude and/or duration. Thus, we recorded $\mathrm{GABA}_{\mathrm{A}}$ picrotoxin-sensitive mIPSCs (Fig. 4D) in the same cells in the presence and absence of 300 $\mu \mathrm{M}$ isoflurane (Fig. $4 A-C$ ). Histograms on Figure $4 E$ indicate that isoflurane significantly increased the decay-time constant 
A
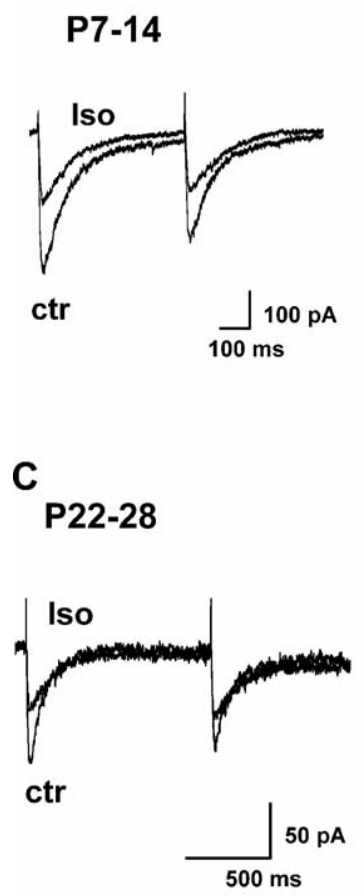

B
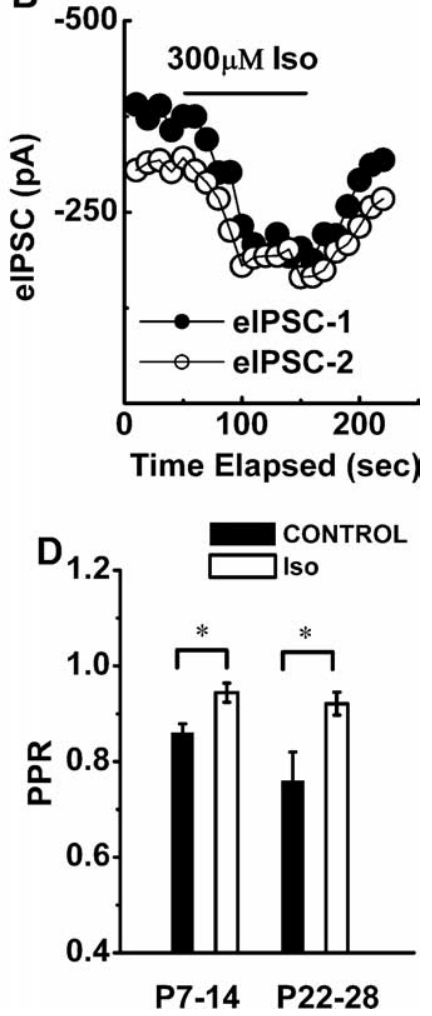

Figure 3. Presynaptic effects of isoflurane applications on eIPSCs in nRT neurons. $\boldsymbol{A}$, Representative traces of evoked $G A B A_{A}$ receptor IPSCS obtained during recording in a paired-pulse protocol before and during application of $300 \mu \mathrm{m}$ isoflurane in an $\mathrm{nRT}$ cell from an immature rat. Isoflurane reversibly blocked $\sim 50 \%$ of elPSCs without changing the holding current. Pairedpulse depression was observed in $98 \%$ of neurons from $n R T$. $B$, Time course from the same cell as that in $\boldsymbol{A}$. Peak values of first (black circles) and second (white circles) evoked IPSCs (at $20 \mathrm{~s}$ intervals) were plotted as a function of time showing the reversible blocking effect of $300 \mu \mathrm{m}$ isoflurane. Horizontal bar indicates duration of isoflurane application. Note that isoflurane more efficiently depressed the first eIPSC. Interval between conditioning and test pulse was $500 \mathrm{~ms}$. C, Representative traces of evoked $G_{A B A_{A}}$ receptor IPSCs obtained during recording in a pairedpulse protocol (interval 1.1 s) before and during application of $300 \mu \mathrm{m}$ isoflurane in an nRT cell from an adult rat. Isoflurane blocked $\sim 50 \%$ of eIPSCs without changing the holding current. Paired-pulse depression was observed in all neurons in this age group. $\boldsymbol{D}$, Histogram bars indicate PPR obtained by dividing the amplitude of eIPSC2/eIPSC1 in control conditions (black bars) and during application of $300 \mu \mathrm{m}$ isoflurane (open bars) in nRT cells from immature (P7-14, $n=10)$ and adult (P22-28, $n=5)$ slices. Isoflurane in both groups increased paired-pulse ratio, strongly suggesting its presynaptic site of action. Asterisks indicate $p<0.05$.

from $52 \pm 3 \mathrm{~ms}$ in controls to $72 \pm 4 \mathrm{~ms}(p<0.01)$ and decreased the frequency of single mIPSC-events from $0.50 \pm 0.06$ $\mathrm{Hz}$ to $0.30 \pm 0.06 \mathrm{~Hz}(p<0.05)$, but had no significant effect on the amplitude of mIPSCs in these cells (control $17.7 \pm 1.4 \mathrm{pA}$, isoflurane $18.3 \pm 1.2 \mathrm{pA}, p>0.05, n=12$ ). The effect of isoflurane on frequency of mIPSCs appears to be strongly correlated with its presynaptic action as described in paired-pulse experiments. However, the increased decay-time constant of mIPSCs and eIPSCs argues for the postsynaptic effect of isoflurane on $\mathrm{GABA}_{\mathrm{A}}$ receptors.

\section{Is there a common presynaptic target for isoflurane and $\mathrm{Ni}^{2+}$ ?}

Different types of voltage-gated $\mathrm{Ca}^{2+}$ channels have an important function in the sensory system and are targeted by many clinically relevant pharmacological agents. It appears that HVA $\mathrm{Ca}^{2+}$ channels (N-, P-, Q-, L-, and R-type) are princi- pally responsible for supporting synaptic transmission (for review, see Catterall, 2000). We found that $\mathrm{Ni}^{2+}$, thought to be selective for R-type in preference to other subtypes of HVA $\mathrm{Ca}^{2+}$ channels (Schneider et al., 1994; Zamponi et al., 1996), when used at a concentration of $100 \mu \mathrm{M}$, reversibly blocked eIPSCs while increasing paired-pulse ratio (Fig. $5 A, B$ ). On average, $\mathrm{Ni}^{2+}$ changed the PPR from $0.72 \pm 0.08$ in controls to $0.85 \pm 0.02(n=5$ cells, $p<0.01)$, strongly suggesting the presynaptic site as a possible target for $\mathrm{Ni}^{2+}$ modulation of eIPSCs.

Our recordings with isoflurane and $\mathrm{Ni}^{2+}$ both showed high potency effects on eIPSCs and PPR suggesting that these agents affect common targets on the presynaptic membrane. To test this possibility, we applied $300 \mu \mathrm{M}$ isoflurane after the exposure of intact slices to $100 \mu \mathrm{M} \mathrm{Ni}^{2+}$, which blocked $\sim 50 \%$ of amplitude of eIPSCs. In this occlusion experiment, we found that $300 \mu \mathrm{M}$ isoflurane had a less prominent effect on the remaining eIPSCs (Fig. 5C,D, representative traces and time course are shown). Overall, isoflurane blocked significantly fewer eIPSC currents after the administration of $\mathrm{Ni}^{2+}(31 \pm 5 \%, n=8$ cells) than it did in control conditions ( $54 \pm 6 \%, n=10$ cells, $p<0.05$ ). Thus, it appears that isoflurane and $\mathrm{Ni}^{2+}$ affect common presynaptic targets in nRT cells. At a concentration of $100 \mu \mathrm{M}, \mathrm{Ni}^{2+}$ was less effective in inhibiting eIPSCs in TC cells $(13 \pm 7 \% ; n=6 ; p<$ 0.001 , data not shown).

Next we tested whether, in intact slice preparations, $100 \mu \mathrm{M}$ $\mathrm{Ni}^{2+}$ and $300 \mu \mathrm{M}$ isoflurane can significantly block HVA Ca ${ }^{2+}$ current, which supports synaptic transmission. Because at least some of the inhibitory synapses in nRT neurons are recurrent connections from the same cells (Cox et al., 1996), we recorded HVA Ca ${ }^{2+}$ currents from the soma of these neurons. In support of our hypothesis, we found that $\mathrm{Ni}^{2+}$ reversibly decreased total HVA Ca ${ }^{2+}$ current amplitude in nRT neurons by $30 \pm 3 \%(n=$ 5 cells, $p<0.01$ ) (Fig. $5 E, F$ ) and that isoflurane similarly inhibited $38 \pm 9 \%$ of total HVA current amplitude $(n=5, p<0.01$, data not shown).

\section{Isoflurane-sensitive R-type $\mathrm{Ca}^{2+}$ channels contribute to inhibitory synaptic transmission in the reticular thalamic nucleus}

The potent blocking effects of $\mathrm{Ni}^{2+}$ on eIPSCs in our experiments were highly suggestive of the possibility that R-type $\mathrm{Ca}^{2+}$ channels are involved in inhibitory synaptic transmission in the thalamus. To investigate the contribution of $\mathrm{R}$-type $\mathrm{Ca}^{2+}$ channels to inhibitory synaptic transmission, we recorded eIPSCs in the presence of SNX-482, a selective R-type channel blocker. Previous studies documented the existence of SNX-482-sensitive R-type current (up to 0.5-1 $\mu \mathrm{M}$ SNX-482) (Newcomb et al., 1998; Tottene et al., 2000). In an earlier study, we found that $0.5 \mu \mathrm{M}$ SNX-482 selectively blocked HVA but not T-type $\mathrm{Ca}^{2+}$ currents in nRT neurons (Joksovic et al., 2005). That is why, in these experiments, we recorded eIPSCs in the presence of $0.5 \mu \mathrm{M} \mathrm{SNX}$ 482. We found that in most cells $0.5 \mu \mathrm{M}$ SNX-482 blocked evoked eIPSCs by $40 \pm 4 \%(n=9, p<0.001)$ (Fig. $6 A, B)$, apparently irreversibly. SNX-482, similar like isoflurane and $\mathrm{Ni}^{2+}$, increased paired-pulse ratio from $0.70 \pm 0.03$ to $0.83 \pm 0.04(n=4, p<$ 0.01 , data not shown), strongly suggesting a presynaptic site of action. Overall, our results indicate that SNX-482-sensitive R-type $\mathrm{Ca}^{2+}$ channels contribute to vesicular GABA release in inhibitory synapses in the thalamus.

Based on our results, we hypothesized that the effect of isoflurane on eIPSCs may be related to its effect on R-type $\mathrm{Ca}^{2+}$ currents. To test this hypothesis, we did two sets of experiments. 
First, in the same neurons, we recorded the effects of $300 \mu \mathrm{M}$ isoflurane on eIPSCs before and after exposure to $0.5 \mu \mathrm{M}$ SNX482. Typical traces and the time course of eIPSCs from this experiment are shown in Figure $6, C$ and $D$. In seven cells studied with this method, the peak amplitude of eIPSCs blocked by $300 \mu \mathrm{M}$ isoflurane was markedly reduced after the application of SNX-482 to $25 \pm 7 \%$. For comparison, $300 \mu \mathrm{M}$ isoflurane blocked $54 \pm 6 \%$ of eIPSCs in control conditions $(p<0.01)$. Thus, a substantial portion of the eIPSCs blocked by isoflurane was removed by the irreversible blocking action of SNX-482 on presynaptic R-type $\mathrm{Ca}^{2+}$ current. Our results strongly suggest that isoflurane modulates eIPSCs in nRT neurons by blocking presynaptic R-type $\mathrm{Ca}^{2+}$ currents.

We then studied the effect of isoflurane on recombinant $\mathrm{Ca}_{\mathrm{V}} 2.3$ R-type $\mathrm{Ca}^{2+}$ channels stably transfected in HEK cells (Nakashima et al., 1998). We found that isoflurane potently and reversibly blocked recombinant human $\mathrm{Ca}_{\mathrm{V}} 2.3$ currents in concentration-dependent manner, yielding an $\mathrm{IC}_{50}$ of $206 \pm 22 \mu \mathrm{M}$ and a Hill slope constant $n$ of $1.66 \pm 0.35$ (Fig. $7 A-C$ ). The slope of the curve and the potency of isoflurane in blocking recombinant $\mathrm{Ca}_{\mathrm{V}} 2.3$ currents were similar to the isoflurane inhibition of eIPSCs shown in Figure 2C.

Under isoflurane anesthesia, alterations of thalamocortical rhythmicity occur in vivo in mice lacking $\mathrm{Ca}_{\mathrm{v}} 2.3$ channels Under a variety of experimental and clinical conditions thalamocortical circuitry in vivo may generate rhythmic oscillations of bursts and blackout sequences (suppressions). This burst-suppression pattern, which is often induced by various volatile anesthetics, including isoflurane (Akrawi et al., 1996), is generally thought to correlate with the blockage of sensory information flow at the thalamic sensory gate (Steriade et al., 1994). Thus, to test the role of $\mathrm{Ca}_{\mathrm{V}} 2.3$ channels in isoflurane anesthesia in vivo, we performed EEG analyses of adult $\mathrm{Ca}_{\mathrm{V}} 2.3 \mathrm{KO}$ mice and WT littermates by systemically determining the number and duration of single-burst or suppression episodes within a representative 10 -min episode after the equilibration period. We performed our in vivo study with $1 \%$ isoflurane, because this concentration approximately correlates with an $\mathrm{IC}_{50}$ for in vitro inhibition of eIPSCs and recombinant $\mathrm{Ca}_{\mathrm{V}} 2.3$ currents.

The representative traces from these experiments are shown in Figure $8, A$ and $B$. At $1 \%$ isoflurane there was a marked, significant difference in duration of suppression episodes between controls ( $3.63 \pm 0.62 \mathrm{~s}, n=3)$ and $\mathrm{Ca}_{\mathrm{v}} 2.3$-deficient mice (1.58 \pm $0.39 \mathrm{~s}, n=3, p<0.05$ ) (Fig. $8 C$, left). In addition, the suppression to burst ratio in $\mathrm{Ca}_{\mathrm{v}} 2.3^{-1-}$ mice was reduced with isoflurane compared with that in controls $(0.211 \pm 0.029$ vs $0.391 \pm 0.049$,
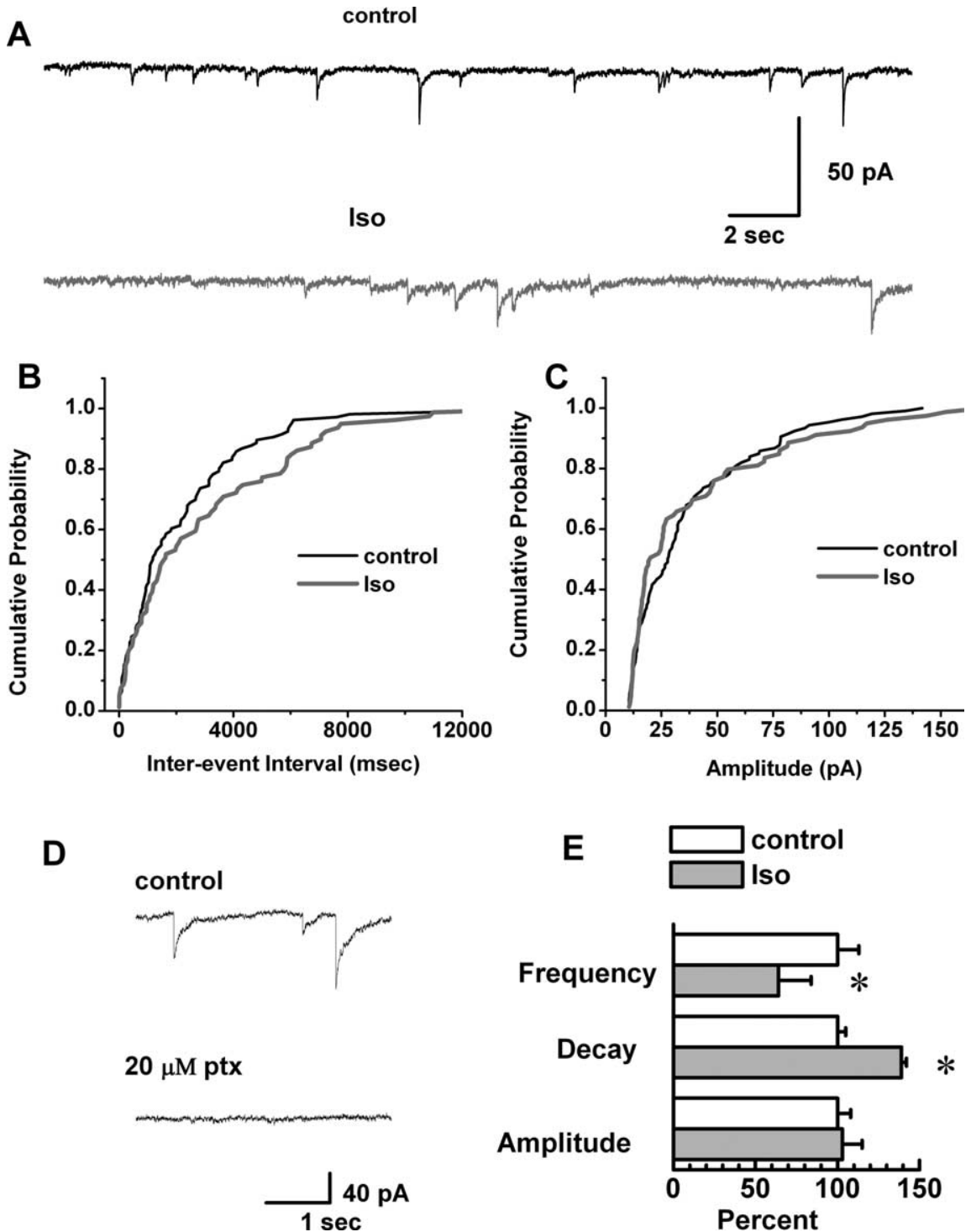

Figure 4. The effect of isoflurane application on mIPSCs in nRT cells. $\boldsymbol{A}$, Traces from representative recording of $\mathrm{mIPSC}$ in the same cell as that shown in $\boldsymbol{A}$. Note the very small effect of isoflurane on the amplitude mIPSCs (from $100 \pm 13 \%$ to $64 \pm 20 \%, p<0.05$ ) and increased the decay time constant (from $100 \pm 5 \%$ to $139 \pm 3 \%, p<$ 0.01 ), but had no significant effect on the mIPSCs peak amplitudes. Data were analyzed and calculated for each cell in a time frame of 250 s per condition ( $n=12$ cells).

$n=3, p<0.05$ ) (Fig. $8 C$, right). The total number of burst and suppression episodes, as well as duration of burst episodes in the presence of isoflurane did not differ significantly between genotypes (data not shown). From each WT and $\mathrm{Ca}_{\mathrm{v}} 2.3 \mathrm{KO}$ mouse, five $2 \mathrm{~s}$ burst episodes were analyzed by PSD in the range from 0 to $100 \mathrm{~Hz}$ to obtain frequency distribution and burst peak frequency. The dominant frequency according to PSD analysis during burst activity was $14.9 \pm 0.9 \mathrm{~Hz}(n=3)$ in WT and $16.0 \pm 2.6$ $\mathrm{Hz}(n=3)$ in $\mathrm{Ca}_{\mathrm{v}} 2.3$ deficient mice $(p>0.05$, data not shown). Overall, our data strongly suggest that $\mathrm{Ca}_{\mathrm{V}} 2.3$ channels contribute to the inhibitory effects of isoflurane on sensory information transfer in corticothalamic circuitry. 


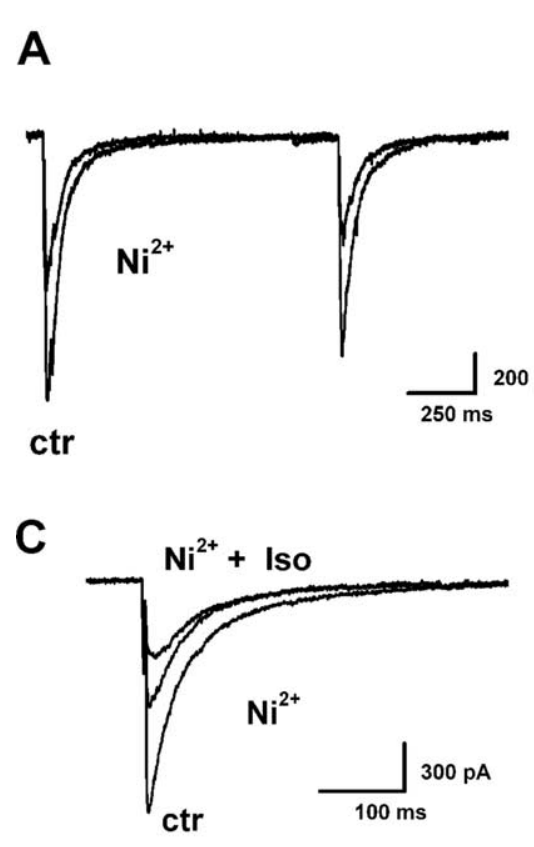

E

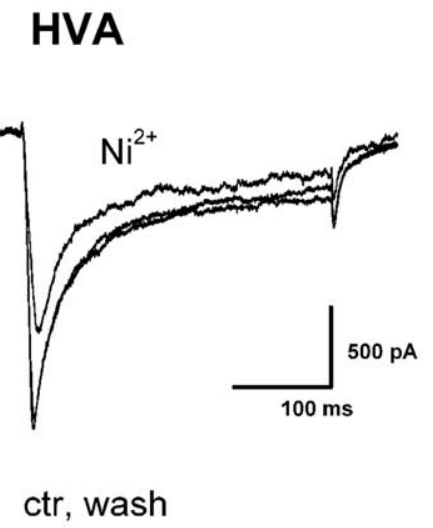

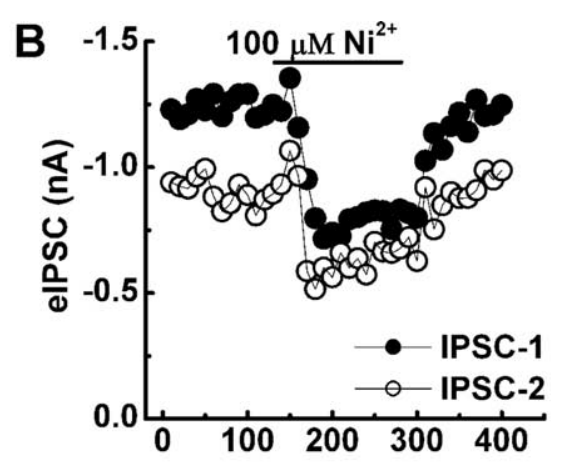
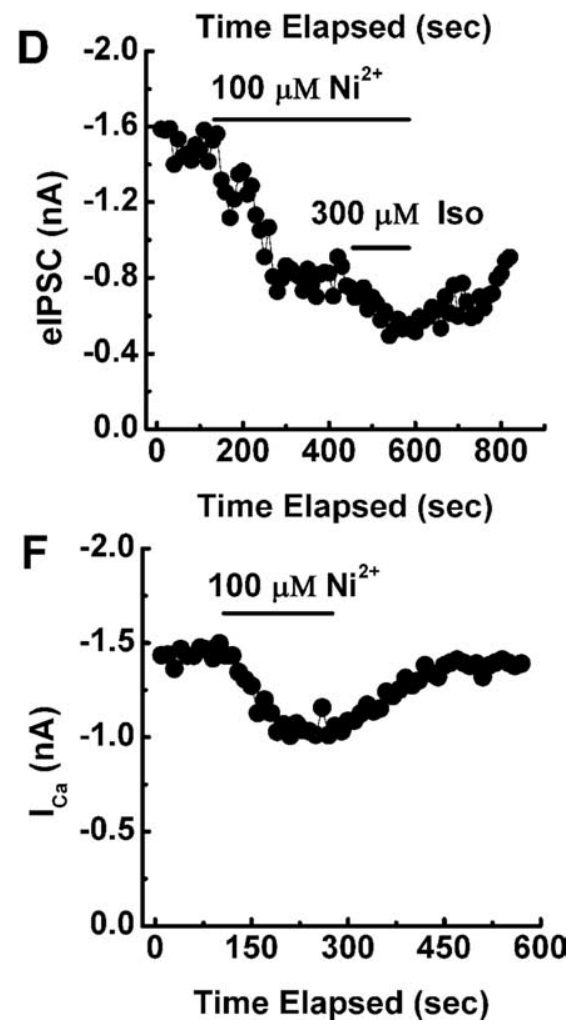

Figure 5. The effect of $\mathrm{Ni}^{2+}$ on elPSCs in $\mathrm{nRT}$ neurons in intact slice preparation. $\boldsymbol{A}$, Representative elPSC traces recorded in paired-pulse protocol in control conditions and in the presence of $100 \mu \mathrm{M} \mathrm{Ni}{ }^{2+}$. Nickel depressed the amplitudes of eIPSCs by $\sim 50 \%$ without apparent effect on kinetics of current decay. Interval between conditioning and test pulse was $1100 \mathrm{~ms}$. B, Time course from the same nRT cell shows the effect of $\mathrm{Ni}^{2+}$ on elPSC1 (filled symbols) and elPSC2 (open symbols). Peak eIPSCs amplitudes were plotted as a function of time. The horizontal bar represents duration of $\mathrm{Ni}^{2+}$ application. C, D, elPSC traces (left) and the corresponding time course (right) showing the occlusive effect of $100 \mu \mathrm{M} \mathrm{Ni}{ }^{2+}$ and $300 \mu \mathrm{m}$ isoflurane on the elPSCs in nRT. Although $300 \mu \mathrm{m}$ isoflurane in the presence of $100 \mu \mathrm{m} \mathrm{Ni}{ }^{2+}$ further decreased the size of elPSC, its overall effect was diminished. $\boldsymbol{E}, \boldsymbol{F}$, Representative traces (left) and time course (right) showing the effect of $100 \mu \mathrm{M} \mathrm{Ni}{ }^{2+}$ on $\mathrm{HVACa}^{2+}$ currents in the same $n R T$ neuron $\left(V_{h}-60 \mathrm{mV}, V_{t} 0 \mathrm{mV}\right) . \mathrm{Ni}^{2+}$ reversibly blocked $\sim 30 \%$ of peak HVACa ${ }^{2+}$ current. Horizontal bar represents duration of $\mathrm{Ni}^{2+}$ application.

\section{Discussion}

Isoflurane-sensitive R-type $\mathrm{Ca}^{2+}$ channels contribute to vesicular release in an inhibitory central synapse

One of our major findings is that R-type $\mathrm{Ca}^{2+}$ channels support inhibitory $\mathrm{GABA}_{\mathrm{A}}$ transmission in $\mathrm{nRT}$ neurons; another is that isoflurane inhibits both evoked and spontaneous inhibitory transmission in these neurons. We also demonstrated that this effect is at least partly mediated by the ability of isoflurane to interact with presynaptic R-type $\mathrm{Ca}^{2+}$ channels.

Depending on the synaptic system being studied, P/Q-, L-, N-, and R-subtypes of HVA currents may contribute to the $\mathrm{Ca}^{2+}$ influx that results in transmitter release (Catterall, 2000). It is generally accepted that most of the fast synaptic transmission in CNS neurons is supported by $\mathrm{P} / \mathrm{Q}$ and $\mathrm{N}$-type $\mathrm{Ca}^{2+}$ channels (Catterall, 2000; Zucker and Regehr, 2002). Because of the paucity of selective blockers, the function of R-type current remains poorly understood. However, it has been shown that this subtype can also support fast excitatory transmitter release in the brainstem (Wu et al., 1998) and in hippocampal (Gasparini et al., 2001) and cerebellar (Brown et al., 2004) neurons. We found that both inhibitory synaptic transmission and recombinant R-type $\mathrm{Ca}^{2+}$ channels are potently inhibited by isoflurane, a commonly used volatile anesthetic. In mammals, the aqueous concentration of isoflurane that correspond to 1 MAC (minimum alveolar concentration that prevents response to a surgical stimulus in $50 \%$ of human subjects) at room temperature is $\sim 320 \mu \mathrm{M}$ (Franks and Lieb, 1994). Therefore, isoflurane concentrations that inhibit IPSCs in nRT cells and recombinant R-type $\mathrm{Ca}_{\mathrm{V}} 2.3$ current are well within the range required for surgical anesthesia.

An early theory of anesthetic mechanisms proposed that nonspecific alteration of the lipid membrane in nerve cells accounts for the anesthetic state (Meyer, 1899; Overton, 1901). However, over the last two decades there has been increasing recognition that specific classes of ion channels in the neuronal membrane are the major cellular targets of general anesthetics. Among the class of ligand-gated ion channels, it appears that the $\mathrm{GABA}_{\mathrm{A}}$ receptor-ion channel complex is central to many effects of general anesthetics. For example, intravenous anesthetics like etomidate and propofol markedly potentiate $\mathrm{GABA}_{\mathrm{A}}$-gated currents; they also prolong decay of GABAergic eIPSCs in CNS neurons as much as fourfold (for review, see Rudolph and Antkowiak, 2004; Urban 2002). Thus, it appears reasonable that modulation of neuronal GABAergic IPSCs may mediate the clinical effects, such as loss of consciousness, of some general anesthetics. In contrast, volatile anesthetic agents such as isoflurane have variable effects on postsynaptic currents mediated by $\mathrm{GABA}_{\mathrm{A}}$ receptors. We found that at $300 \mu \mathrm{M}$, isoflurane caused an increase of $\sim 40-50 \%$ in the decay time constant of mIPSCs and eIPSCs in nRT neurons. However, it seems that inhibition of presynaptic R-type $\mathrm{Ca}^{2+}$ currents and a consequent decrease in the amplitude of eIPSCs with the same concentration of isoflurane can overcome these effects, because it resulted in an overall decrease of net-charge transfer. However, even though in situ hybridization studies have demonstrated presence of mRNA for $\mathrm{Ca}_{\mathrm{V}} 2.3$ channels in nRT neurons (Williams et al., 1994), direct substantiation of functional presynaptic $\mathrm{Ca}_{\mathrm{V}} 2.3$ proteins in $\mathrm{nRT}$ 
A
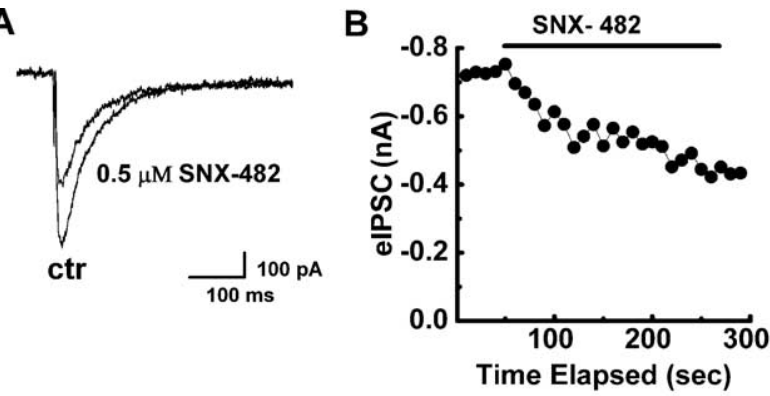

C
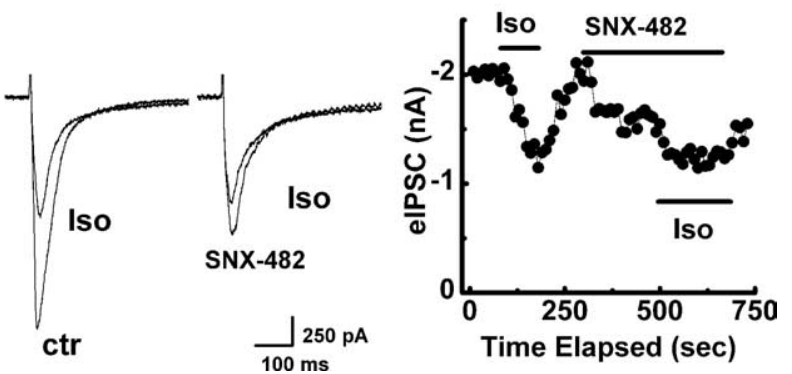

Figure 6. SNX-482-sensitive R-type $\mathrm{Ca}^{2+}$ channels contribute to generation of elPSCs in $\mathrm{nRT}$ neurons. $\boldsymbol{A}, \boldsymbol{B}$, Representative elPSC traces and time course on right recorded before and during application of $0.5 \mu \mathrm{m}$ SNX-482, showing its effect on peak amplitude of elPSCs. The effect of SNX-482 slowly reached a stable maximal level. There was little effect on the kinetics of eIPSCs. C, Representative eIPSCs traces showing the effect of isoflurane on an nRT neuron exposed to SNX-482. After control application of $300 \mu \mathrm{m}$ isoflurane, $0.5 \mu \mathrm{m}$ SNX-482 was applied until stable eIPSCs were obtained, after which the neuron was reexposed to the same concentration of isoflurane. Traces originate from the same cell and are separated for clarity. Isoflurane blocked fewer eIPSCS after SNX-sensitive current was blocked. D, Peak eIPSC amplitudes from the same cell as that depicted in panel $C$ are plotted as a function of time. The reversible blocking effect of is oflurane on the amplitude of elPSCs was diminished $\sim 60 \%$ in the presence of SNX-482.

neurons is difficult because nerve terminals are too small for patch-clamping and validated subtype-specific $\mathrm{Ca}_{\mathrm{V}} 2.3$ antibodies are not readily available.

Previous studies have indicated that at clinically relevant concentrations isoflurane has smaller effects on other subtypes of $\mathrm{HVA} \mathrm{Ca}^{2+}$ channels. For example, P-type $\mathrm{Ca}^{2+}$ currents in cerebellar Purkinje neurons were inhibited to $<10 \%$ by $350 \mu \mathrm{M}$ isoflurane (Hall et al., 1994). At $310 \mu \mathrm{M}$, isoflurane inhibited $\sim 14 \%$ of recombinant $\mathrm{N}$-type $\mathrm{Ca}^{2+}$ current in HEK cells (White et al., 2005). In contrast, we found that at $300 \mu \mathrm{M}$, isoflurane inhibited $>50 \%$ of recombinant $\mathrm{Ca}_{\mathrm{V}} 2.3 \mathrm{R}$-type current and, with similar potency, inhibited vesicular release in nRT neurons. In agreement with our results, Kamatchi et al. (1999) found that 350 $\mu \mathrm{M}$ isoflurane inhibited $\sim 45 \%$ of recombinant $\mathrm{Ca}_{\mathrm{V}} 2.3$ current in Xenopus oocytes.

Thus, it appears that among other HVA $\mathrm{Ca}^{2+}$ channels, $\mathrm{Ca}_{\mathrm{V}} 2.3$ have unique sensitivity to isoflurane. However, the relationship between $\mathrm{Ca}^{2+}$ ions and synaptic release is nonlinear (Katz and Miledi, 1970; Catterall, 2000; Zucker and Regehr, 2002). Also, neither SNX-482 nor $\mathrm{Ni}^{2+}$ completely occluded the effects of isoflurane on eIPSCs in our experiments. One possibility that cannot be ruled out is that blockade of $\mathrm{P} / \mathrm{Q}$ or $\mathrm{N}$-type, along with R-type $\mathrm{Ca}^{2+}$ currents, by isoflurane also contributes to the inhibition of eIPSCs in nRT neurons. This is particularly important in cases in which multiple $\mathrm{Ca}^{2+}$ channel subtypes contribute to vesicular release in the same synapse. We previously reported that recombinant and native T-type $\mathrm{Ca}^{2+}$ channels ( $\mathrm{T}$ -
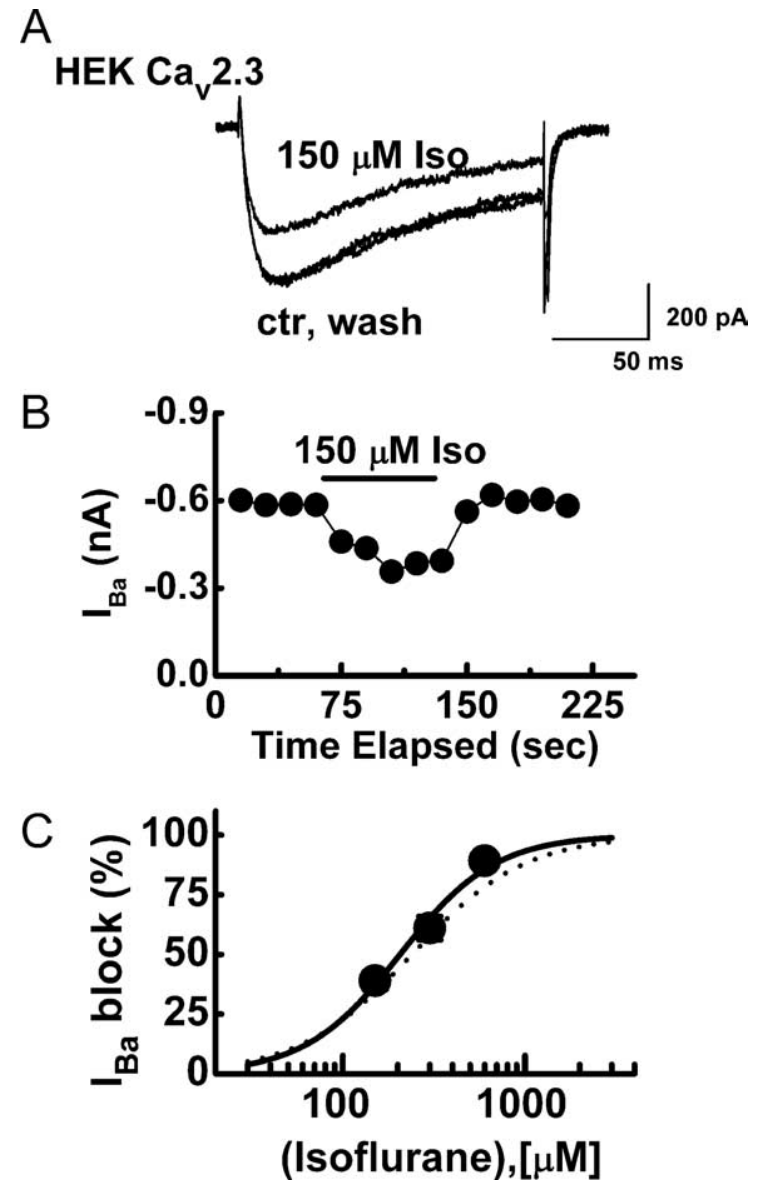

Figure 7. Isoflurane blocks human recombinant $\mathrm{Ca}_{\mathrm{v}} 2.3$ currents in HEK cells. $\boldsymbol{A}$, Family of inward barium currents $\left(V_{\mathrm{h}}-70 \mathrm{mV}, V_{\mathrm{t}} 0 \mathrm{mV}\right)$ recorded from HEK cells stably transfected with $\mathrm{Ca}_{\mathrm{v}} 2.3$ channels before, during, and after application of $150 \mu \mathrm{m}$ isoflurane. $\boldsymbol{B}$, Time course from the same cell illustrating the reversible blocking effect of $150 \mu \mathrm{m}$ isoflurane on recombinant human $\mathrm{Ca}_{\mathrm{v}} 2.3$ currents. Horizontal bar indicates the time of isoflurane application. C, Solid line represents concentration-response curve best fitted with Hill function showing the effect of isoflurane on recombinant $\mathrm{Ca}_{\mathrm{v}} 2.3$ currents, which yielded an $\mathrm{IC}_{50}$ of $206 \pm 22 \mu \mathrm{m}$ and a slope constant $n$ of $1.66 \pm 0.35$. Each point on the curve is calculated as a mean from at least 6 cells. Dashed line represents concentration-response curve for isoflurane inhibition of elPSCs in intact nRT neurons in brain slices (from Fig. 2C). Note that the two lines almost overlap.

channels) are potently inhibited by volatile anesthetics, including isoflurane (Todorovic and Lingle, 1998; Todorovic et al., 2000; Joksovic et al., 2005). However, T-channels are usually localized at somatic and dendritic compartments of neurons in CNS and are less likely to contribute to synaptic vesicular release. Furthermore, whereas $\mathrm{Ni}^{2+}$ blocks both families of channels with similar potency (Randall and Tsien, 1997), our results with SNX-482, which does not block T-currents in nRT neurons (Joksovic et al., 2005), argue that R-type channels are involved in vesicular release.

Is there functional significance in the inhibition of IPSCs by isoflurane in $\mathrm{nRT}$ neurons?

A complete anesthetic state involves loss of consciousness (hypnosis), movement (immobilization), pain sensation (analgesia), and recollection of the event (amnesia). In addition, most volatile general anesthetics, including isoflurane, have muscle relaxant and anticonvulsant properties. New theories propose that multiple end-points of anesthesia are mediated by multiple relevant cellular mechanisms (Urban, 2002; Rudolph and Antkowiak, 2004; Franks, 2008). According to this hypothesis, which molec- 

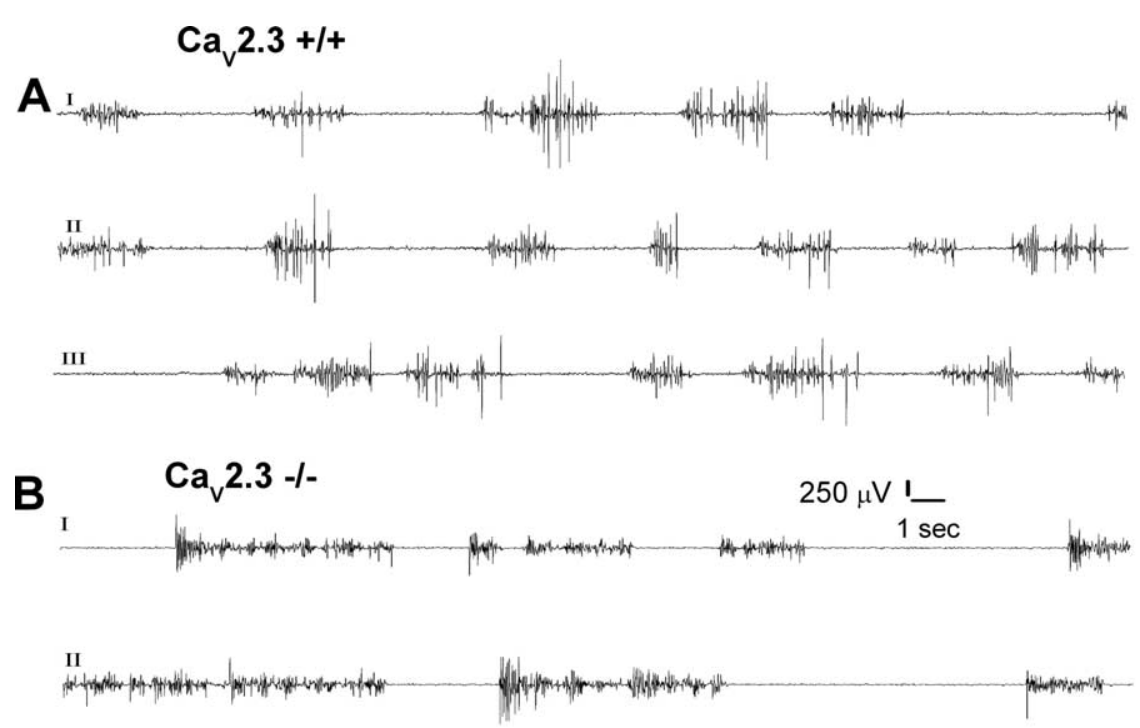

III

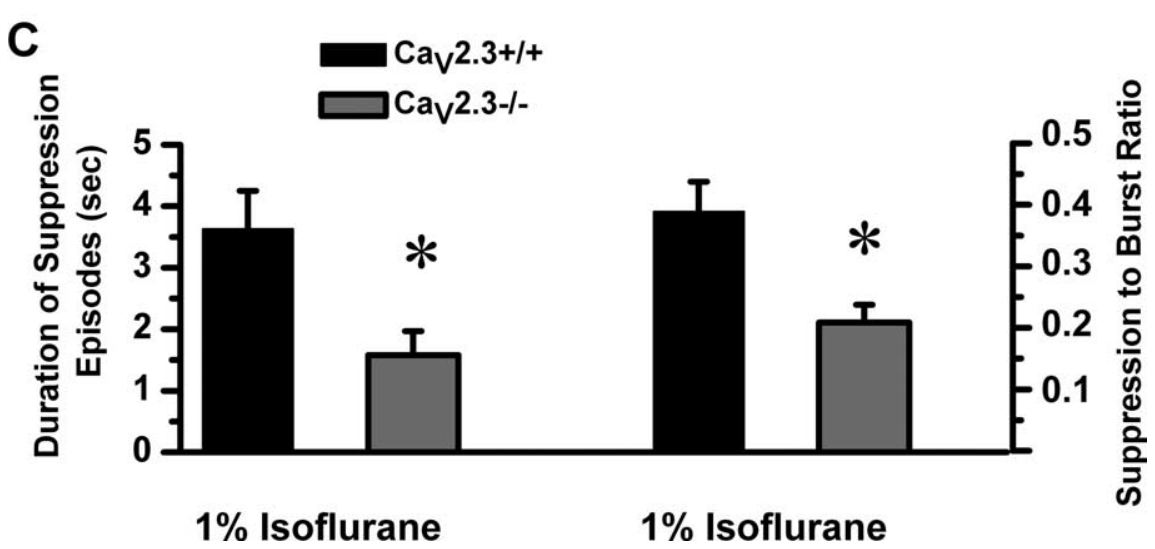

Figure 8. Alterations of isoflurane-induced burst-suppression EEG pattern in Ca $2.3 \mathrm{KO}$ mice. $\boldsymbol{A}$, Representative traces of EEG recordings under anesthesia with $1 \%$ isoflurane in a wild-type $\left(\mathrm{Ca}_{\mathrm{v}} 2.3^{+/+}\right)$mouse. Note periods of alternating bursting activity and flatness (suppression) in recordings. $\boldsymbol{B}$, Representative traces of EEG recordings under anesthesia with $1 \%$ isoflurane in a $\mathrm{Ca}_{\mathrm{v}} 2.3^{-1-}$ mouse. Note shorter periods of suppression pattern (flat line) compared with $\boldsymbol{A}$. Calibration bars pertain to $\boldsymbol{A}$ and $\boldsymbol{B}$ of this figure. $\boldsymbol{C}$, On the left, suppression episodes have been analyzed for their average duration within a 10-min period after equilibration of isoflurane. The suppression duration with isoflurane is significantly decreased in $\mathrm{Ca}_{v} 2.3^{-1-}$ mice (gray filled bars) compared with WT littermates (black filled bars) (asterisk indicates $p<0.05$ ). On the right, the suppression to burst ratio is significantly reduced in $\mathrm{a}_{\mathrm{v}} 2.3$-deficient mice (gray filled bars) compared with controls (black filled bars), which correlates with the strong reduction in suppression duration. Asterisk indicates $p<0.05$.

ular target is important depends on the specific anesthetic and the specific end point in consideration.

The thalamus is a major "gateway" of corticothalamocortical functional connections. These functions are essential for awareness and cognitive functions, such as learning and memory, as well as sleep-wake cycles and epileptogenesis (Kinney et al., 1994; Llinás et al., 1999; McAlonan and Brown, 2002). Functional imaging studies in both humans and other animals have led to the theory that direct and indirect depression of thalamocortical neurons provide a convergent point for neural pathways of anesthetic action leading to a sleep-like state (Alkire et al., 2000). Mutually interconnected cortical, nRT, and thalamic relay neurons exhibit phasic behaviors such as tonic and burst firing that represent different functional modes (McCormick and Bal, 1997). During tonic firing, which predominates during awake states, there is a faithful transfer of sensory information to cortical neurons. In contrast, during slow oscillations that occur with a T-channeldependent burst firing pattern of these neurons, there is impairment of sensory transfer and transition to sleep states. In agreement with this, $\mathrm{Ca}_{\mathrm{V}} 3.1$ T-channel knock-out mice not only show slower anesthetic induction (Petrenko et al., 2007), but have an abnormal natural sleep phenotype that likely results from the lack of $\mathrm{T}$-channels and underlying burst firing in thalamic relay neurons (Lee et al., 2004; Anderson et al., 2005).

Inhibitory GABAergic nRT neurons are crucial in these oscillations because their activation provides hyperpolarization of membrane potential in thalamic relay neurons. This, in turn, initiates transition to a bursting mode by deinactivating T-channels. It is difficult to predict what the particular consequence of inhibition of $\mathrm{Ca}_{\mathrm{V}} 2.3$ channels and IPSCs per se in nRT cells might be in this complicated loop. However, given that nRT neurons are uniformly inhibitory, it is likely that decreasing feedback inhibition to these cells with isoflurane would initially favor a slow oscillatory mode of thalamic neurons. However, with the progressive hyperpolarization of neuronal membrane and the consequent shunting of action potentials associated with deeper anesthetic states, this could contribute to a suppression pattern and eventually lead to a completely flat line on EEG, which generally correlates with a block of sensory information at the level of the thalamic sensory gate (Steriade et al., 1994). In support of this view, we found a decrease in the duration of suppression episodes in EEG under in vivo isoflurane anesthesia in $\mathrm{Ca}_{\mathrm{V}} 2.3 \mathrm{KO}$ mice. However, if we are to obtain a comprehensive picture, more information will be needed regarding the effects of isoflurane on ion channels other than $\mathrm{GABA}_{\mathrm{A}}$ in corticothalamic circuitry in both normal animals and $\mathrm{Ca}_{\mathrm{V}} 2.3 \mathrm{KO}$ animals. For example, it is possible that the effects of anesthetics on both $\mathrm{GABA}_{\mathrm{A}}$ and $\mathrm{K}^{+}$conductance could contribute to suppression episodes in EEG (Steriade et al., 1994). Additionally, because molecular studies indicate that $\mathrm{Ca}_{\mathrm{v}} 2.3$ is ubiquitously expressed in neurons including cerebral cortex (Williams et al., 1994), the alterations in EEG pattern could have been the result of effects of isoflurane on thalamic and/or cortical $\mathrm{Ca}_{\mathrm{V}} 2.3$ R-type channels. Future studies with thalamusspecific $\mathrm{Ca}_{\mathrm{V}} 2.3 \mathrm{KO}$ mice would be useful to address this issue.

In conclusion, we found that isoflurane at clinically relevant concentrations inhibits functional presynaptic R-type $\mathrm{Ca}^{2+}$ channels in the nRT neurons. Furthermore, these channels are ubiquitously expressed in neurons, where they have a crucial function in regulating fundamental properties of synaptic transmitter release. Thus, the potential involvement of presynaptic HVA Ca ${ }^{2+}$ channels as molecular targets for volatile general anesthetics warrants consideration. 


\section{References}

Akrawi WP, Drummond JC, Kalkman CJ, Patel PM (1996) A comparison of the electrophysiologic characteristics of EEG burst-suppression as produced by isoflurane, thiopental, etomidate, and propofol. J Neurosurg Anesthesiol 8:40-46.

Alkire MT, Haier RJ, Fallon JH (2000) Toward a unified theory of narcosis: brain imaging evidence for a thalamocortical switch as the neurophysiologic basis of anesthetic-induced unconsciousness. Conscious Cogn 9:370-386

Anderson MP, Mochizuki T, Xie J, Fischler W, Manger JP, Talley EM, Scammell TE, Tonegawa S (2005) Thalamic Cav3.1 T-type Ca2+ channel plays a crucial role in stabilizing sleep. Proc Natl Acad Sci U S A 102:1743-1748.

Angel A (1991) Adventures in anesthesia. Exp Physiol 76:1-38.

Asanuma C (1994) GABAergic and pallidal terminals in the thalamic reticular nucleus of squirrel monkeys. Exp Brain Res 101:439-451.

Bessaïh T, Bourgeais L, Badiu CI, Carter DA, Toth TI, Ruano D, Lambolez B, Crunelli V, Leresche N (2006) Nucleus-specific abnormalities of GABAergic synaptic transmission in a genetic model of absence seizures. J Neurophysiol 96:3074-3081.

Brown SP, Safo PK, Regehr WG (2004) Endocannabinoids inhibit transmission at granule cell to Purkinje cell synapses by modulating three types of presynaptic calcium channels. J Neurosci 24:5623-5631.

Catterall WA (2000) Structure and regulation of voltage-gated $\mathrm{Ca}^{2+}$ channels. Annu Rev Cell Dev Biol 16:521-555.

Cox CL, Huguenard JR, Prince DA (1996) Heterogeneous axonal arborizations of rat thalamic reticular neurons in the ventrobasal nucleus. J Comp Neurol 366:416-430.

Detsch O, Kochs E, Siemers M, Bromm B, Vahle-Hinz C (2002) Differential effects of isoflurane on excitatory and inhibitory synaptic inputs to thalamic neurones in vivo. Br J Anaesth 89:294-300.

Franks NP (2008) General anaesthesia: from molecular targets to neuronal pathways of sleep and arousal. Nat Rev Neurosci 9:370-386.

Franks NP, Lieb WR (1994) Molecular and cellular mechanisms of general anesthesia. Nature 367:607-614.

Franks NP, Dickinson R, de Sousa SL, Hall AC, Lieb WR (1998) How does xenon produce anaesthesia? Nature 396:324.

Gasparini S, Kasyanov AM, Pietrobon D, Voronin LL, Cherubini E (2001) Presynaptic R-type calcium channels contribute to fast excitatory synaptic transmission in the rat hippocampus. J Neurosci 21:8715-8721.

Hall AC, Lieb WR, Franks NP (1994) Insensitivity of P-type calcium channels to inhalational and intravenous general anesthetics. Anesthesiology $81: 117-123$.

Herrington J, Stern RC, Evers AS, Lingle CJ (1991) Halothane inhibits two components of calcium current in clonal $\left(\mathrm{GH}_{3}\right)$ pituitary cells. J Neurosci 11:2226-2240.

Huntsman MM, Huguenard JR (2000) Nucleus-specific differences in $\mathrm{GABA}_{\mathrm{A}}$-receptor-mediated inhibition are enhanced during thalamic development. J Neurophysiol 83:350-358.

Huguenard JR, Prince DA (1992) A novel T-type current underlies prolonged $\mathrm{Ca}^{2+}$-dependent burst firing in GABAergic neurons of rat thalamic reticular nucleus. J Neurosci 12:3804-3817.

Jevtović-Todorović V, Todorović SM, Mennerick S, Powell S, Dikranian K, Benshoff N, Zorumski CF, Olney JW (1998) Nitrous oxide (laughing gas) is an NMDA antagonist, neuroprotectant and neurotoxin. Nat Med 4:460-463.

Joksovic PM, Bayliss DA, Todorovic SM (2005) Different kinetic properties of two T-type $\mathrm{Ca}^{2+}$ currents of rat reticular thalamic neurons and their modulation by enflurane. J Physiol 566:125-142.

Jones EG (1985) The thalamus. New York: Plenum.

Jourdain A, Semba K, Fibiger HC (1989) Basal forebrain and mesopontine tegmental projections of the reticular thalamic nucleus: an axonal collateralization and immunohistological study in the rat. Brain Res 505:55-65.

Kamatchi GL, Chan CK, Snutch T, Durieux ME, Lynch C 3rd (1999) Volatile anesthetic inhibition of neuronal Ca channel currents expressed in Xenopus oocytes. Brain Res 831:85-96.

Katz B, Miledi R (1970) Further study of the role of calcium in synaptic transmission. J Physiol 207:789-801.

Kinney HC, Korein J, Panigrahy A, Dikkes P, Goode R (1994) Neuropathological findings in the brain of Karen Ann Quinlan: the role of the thalamus in the persistent vegetative state. N Engl J Med 330:1469-1475.

Lee J, Kim D, Shin HS (2004) Lack of delta waves and sleep disturbances during non-rapid eye movement sleep in mice lacking alpha1G-subunit of T-type calcium channels. Proc Natl Acad Sci U S A 101:18195-18199.

Llinás RR, Ribary U, Jeanmonod D, Kronberg E, Mitra PP (1999) Thalamocortical dysrhythmia: a neurological and neuropsychiatric syndrome characterized by magnetoencephalography. Proc Natl Acad Sci U S A 96:15222-15227.

McAlonan K, Brown VJ (2002) The thalamic reticular nucleus: more than a sensory nucleus? Neuroscientist 8:302-305.

McCormick DA, Bal T (1997) Sleep and arousal: thalamocortical mechanisms. Annu Rev Neurosci 20:185-215.

McDowell TS, Pancrazio JJ, Lynch C 3rd (1996) Volatile anesthetics reduce low-voltage-activated calcium currents in a thyroid C-cell line. Anesthesiology 85:1167-1175.

Mennerick S, Jevtovic-Todorovic V, Todorovic SM, Shen W, Olney JW, Zorumski CF (1998) Effects of nitrous oxide (laughing gas) on excitatory and inhibitory synaptic transmission in hippocampal cultures. J Neurosci 18:9716-9726.

Meyer H (1899) Zur Theorie der Alcoholnarkose. Arch Exp Pathol Pharmacol 42:109-118.

Nakashima YM, Todorovic SM, Pereverzev A, Hescheler J, Schneider T, Lingle CJ (1998) Properties of $\mathrm{Ca}^{2+}$ currents arising from human $\alpha_{1 \mathrm{E}}$ and $\alpha_{1 \mathrm{E}} \beta_{3}$ constructs expressed in HEK293 cells: physiology, pharmacology, and comparison to native T-type $\mathrm{Ca}^{2+}$ currents. Neuropharmacology 37:957-972.

Newcomb R, Szoke B, Palma A, Wang G, Chen X, Hopkins W, Cong R, Miller J, Urge L, Tarczy-Hornoch K, Loo JA, Dooley DJ, Nadasdi L, Tsien RW, Lemos J, Miljanich G (1998) Selective peptide antagonist of the class E calcium channel from the venom of the tarantula Hysterocrates gigas. Biochemistry 37:15353-15362.

Overton S (1901) Studien Uber die Narkose Zugleich Ein Beitrag Zur Allgemeinen Pharmakologie. Jena: Verlag von Gustav Fischer.

Paré D, Hazrati LN, Parent A, Steriade M (1990) Substantia nigra pars reticulate projects to the reticular thalamic nucleus of the cat: a morphological and electrophysiological study. Brain Res 535:139-146.

Paxinos G, Watson C (1986) The rat brain in stereotaxic coordinates. Sydney: Academic.

Pereverzev A, Mikhna M, Vajna R, Gissel C, Henry M, Weiergräber M, Hescheler J, Smyth N, Schneider T (2002) Disturbances in glucosetolerance, insulin-release, and stress-induced hyperglycemia upon disruption of the $\mathrm{Ca}(\mathrm{v}) 2.3$ (alpha $1 \mathrm{E}$ ) subunit of voltage-gated $\mathrm{Ca}(2+)$ channels. Mol Endocrinol 16:884-895.

Petrenko AB, Tsujita M, Kohno T, Sakimura K, Baba H (2007) Mutation of alpha1G T-type calcium channels in mice do not change the anesthetic requirements for loss of righting reflex and minimum alveolar concentration but delays the onset of anesthetic induction. Anesthesiology 106:1177-1185.

Randall AD, Tsien RW (1997) Contrasting biophysical and pharmacological properties of T-type and R-type calcium channels. Neuropharmacology 36:879-893.

Rudolph U, Antkowiak B (2004) Molecular and neuronal substrates for general anaesthetics. Nat Rev Neurosci 5:709-720.

Sanchez-Vives MV, Bal T, McCormick DA (1997) Inhibitory interactions between perigeniculate GABAergic neurons. J Neurosci 17:8894-8908.

Schneider T, Wei X, Olcese R, Costantin JL, Neely A, Palade P, Perez-Reyes E, Qin N, Zhou J, Crawford GD, Smith RG, Appel SH, Stefani E, Birnbaumer L (1994) Molecular analysis and functional expression of the human type E neuronal $\mathrm{Ca}^{2+}$ channel alpha 1 subunit. Receptors Channels 2:255-270.

Shu Y, McCormick DA (2002) Inhibitory interactions between ferret thalamic reticular neurons. J Neurophysiol 87:2571-2576.

Steriade M, Amzica F, Contreras D (1994) Cortical and thalamic cellular correlates of electroencephalographic burst-suppression. Electroencephalogr Clin Neurophysiol 90:1-16.

Stevens WC, Kingston HGG (1992) Inhalation anesthesia. In: Clinical anesthesia, Ed 2 (Barash PG, ed), pp 429-465. Philadelphia: Lippincott.

Study RE (1994) Isoflurane inhibits multiple voltage-gated calcium current in hippocampal pyramidal neurons. Anesthesiology 81:104-116.

Takenoshita M, Steinbach JH (1991) Halothane blocks low-voltageactivated calcium current in rat sensory neurons. J Neurosci 11:1404-1412.

Todorovic SM, Lingle CJ (1998) Pharmacological properties of T-type 
$\mathrm{Ca}^{2+}$ current in adult rat sensory neurons: effects of anticonvulsant and anesthetic agents. J Neurophysiol 79:240-252.

Todorovic SM, Perez-Reyes E, Lingle CJ (2000) Anticonvulsants but not general anesthetics have differential blocking effects on different T-type current variants. Mol Pharmacol 58:98-108.

Tottene A, Volsen S, Pietrobon D (2000) Alpha (1E) subunits form the pore of three cerebellar R-type calcium channels with different pharmacological and permeation properties. J Neurosci 20:171-178.

Urban BW (2002) Current assessment of targets and theories of anaesthesia. Br J Anaesth 89:167-183.

Vahle-Hinz C, Detsch O, Hackner C, Kochs E (2007a) Corresponding minimum alveolar concentrations of isoflurane and isoflurane/nitrous oxide have divergent effects on thalamic nociceptive signalling. Br J Anaesth 98:228-235.

Vahle-Hinz C, Detsch O, Siemers M, Kochs E (2007b) Contributions of GABAergic and glutamatergic mechanisms to isoflurane-induced suppression of thalamic somatosensory information transfer. Exp Brain Res 176:159-172.

Weiergräber M, Henry M, Hescheler J, Smyth N, Schneider T (2005) Electrocorticographic and deep intracerebral EEG recording in mice using a telemetry system. Brain Res Brain Res Protoc 14:154-164.

Weiergräber M, Henry M, Krieger A, Kamp M, Radhakrishnan K, Hescheler
J, Schneider T (2006) Altered seizure susceptibility in mice lacking the Ca(v) 2.3 E-type Ca2+ channel. Epilepsia 47:839-850.

White IL, Franks NP, Dickinson R (2005) Effects of isoflurane and xenon on $\mathrm{Ba} 2+$-currents mediated by $\mathrm{N}$-type calcium channels. Br J Anaesth 94:784-790.

Williams ME, Marubio LM, Deal CR, Hans M, Brust PF, Philipson LH, Miller RJ, Johnson EC, Harpold MM, Ellis SB (1994) Structure and functional characterization of neuronal alpha $1 \mathrm{E}$ calcium channel subtypes. J Biol Chem 269:22347-22357.

Wu LG, Saggau P (1997) Presynaptic inhibition of elicited neurotransmitter release. Trends Neurosci 20:204-212.

Wu LG, Borst JG, Sakmann B (1998) R-type $\mathrm{Ca}^{2+}$ currents evoke transmitter release at a rat central synapse. Proc Natl Acad Sci U S A 95:4720-4725.

Zamponi GW, Bourinet E, Snutch TP (1996) Nickel block of a family of neuronal calcium channels: subtype- and subunit-dependent action at multiple sites. J Membr Biol 151:77-90.

Zhang SJ, Huguenard JR, Prince DA (1997) $\mathrm{GABA}_{\mathrm{A}}$ receptor-mediated $\mathrm{Cl}^{-}$ currents in rat thalamic reticular and relay neurons. J Neurophysiol 78: 22890-22896.

Zucker RS, Regehr WG (2002) Short-term synaptic plasticity. Annu Rev Physiol 64:355-405. 